$\left.L^{\prime 2}\right|_{\text {LA-5106-PR }}$

\title{
PROGRESS REPORT \\ 2
}

\section{$D R+384$}

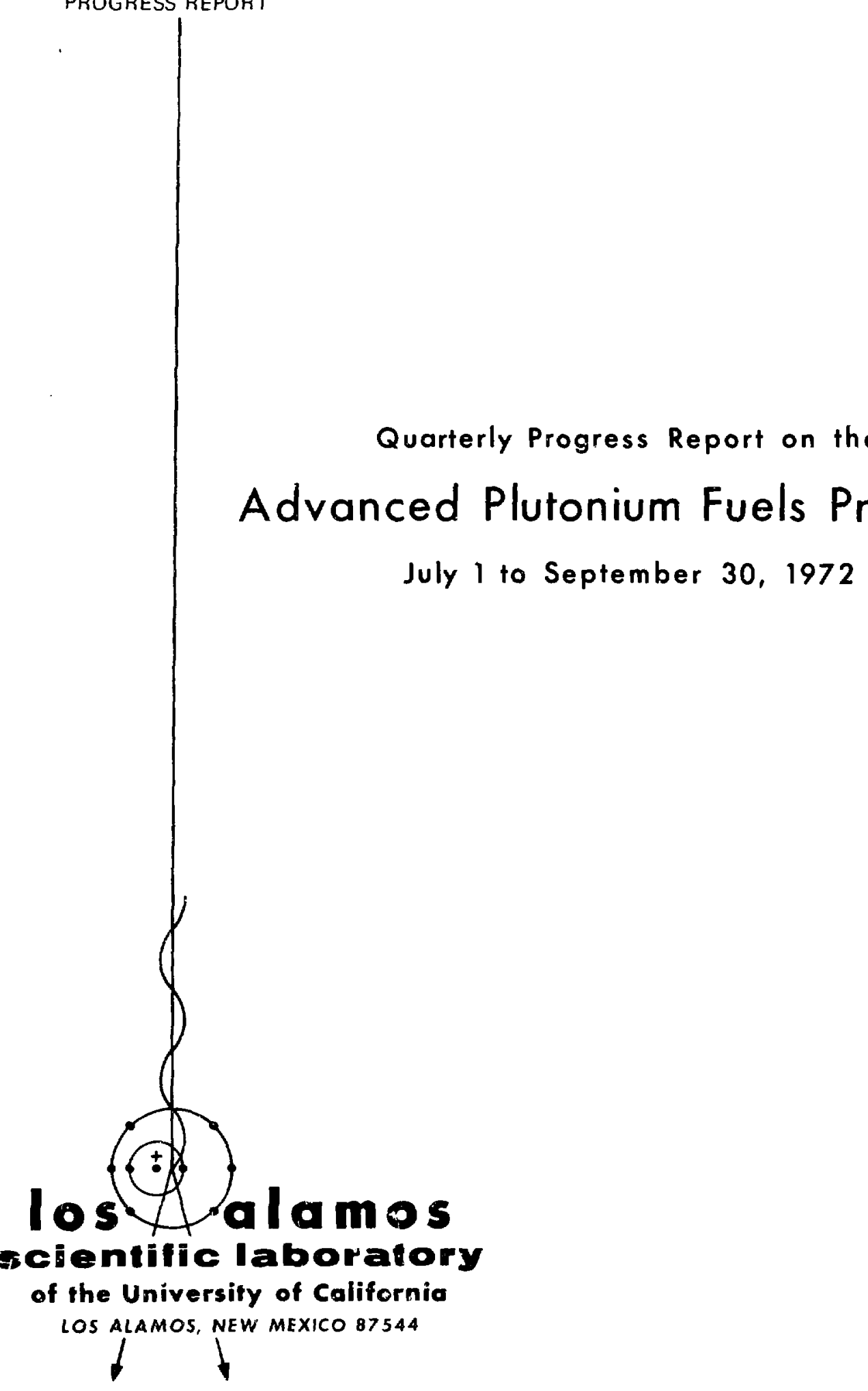


This report was prepared as an account of work sponsored ty the United States Government. Neither the United States nor the United States Atomic Energy Cornmission. nor any of their employees, nor any of their contractors, subcontractors, or their employees, makes any warranty, express or im. plied, or assum,es any legal liability or responsibility for the accuracy, completeness or usetulness of any information, apperatus, product or process disclosed, or represents that its use would not infringe privately owned rights.

This report presents the status of the LASL Advanced Plutonium Fuels program. The four most recent reports in this series, all unclassified, are:

$$
\begin{array}{ll}
\text { LA.4841-MS } & \text { LA-4993-PR } \\
\text { LA-4913-PR } & \text { LA-5067-PR }
\end{array}
$$

In the interest of prompt distribution, this progress report was not edited by the Technical Information staff.

Printed in the United States of America. Aivailable from

National Technical Information Service

U. S. Department of Commerce 5285 Port Royal Road

Springfield, Virginia 22151

Price: Printed Copy $\$ 3.00$; Microfiche $\$ 0.95$ 


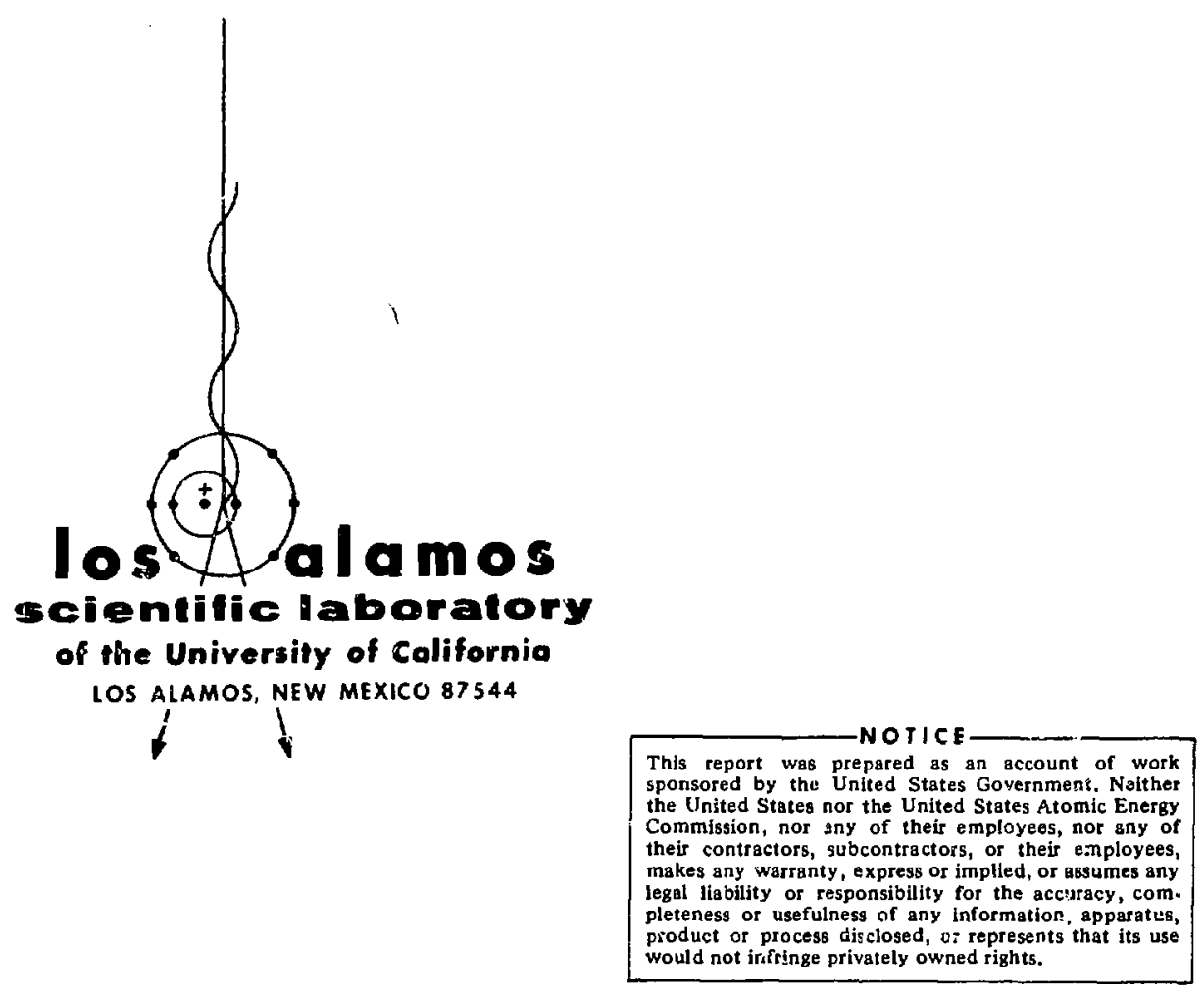

\section{LA-5106-PR}

Progress Report

UC-79-b

ISSUED: November 1972

This report was prepared as an account of work The the United States Governmen's. Naither United States nor the United States Atomic Energy Com of their employess, nor sny of contractors, subcontractors, or their employees, yarranty, express or impled or assumes any product or process disclosed, of represents that its use would not irifringe privately owned rights.

Quarterly Progress Report on the

\section{Advanced Plutonium Fuels Program}

July 1 to September 30, 1972

Compiled by

R. D. Baker

This work supported by the Division of Reactor Development and Technology, U.S. Atomic Energy Commission. 
I. Introduction 1

II. Equipment Deyelopment $\quad 1$

III. Microstructural Analysis $\quad 3$

IV. Installation of Automatic Photographic Equipment 3

V. Hot Cell Facility at DP West

VI. Analytical Chemistry $\quad 3$

$\begin{array}{ll}\text { VII. } & \text { Requests from DRDT }\end{array}$

VIII. Publications and Talks $\quad 7$

$\begin{array}{ll}\text { IX. References } & 7\end{array}$

463 HIGH PERFORMANCE LMFBR FUEL MATERIALS $\quad 8$

$\begin{array}{ll}\text { I. Introduction } & 8\end{array}$

$\begin{array}{ll}\text { II. Irradiation Testing } & 8\end{array}$

III. Fuel Property Measurements 21

IV. References $\quad 22$

I. Analytical Chemistry Program for Boron Carbide 23

III. Analytical Chemistry Program for FFR Mixed Oxide Fuel 25 


\section{ABSTRACT}

This is the 24th quarterly report on the Advanced Plutonium Fuels Program at the Los Alamos Scientific Laboratory.

Most of the investigations discussed here are of the continuing type. Results and conclusions described may therefore be changed or augmented as the work continues. Published reference to results cited in tlis report should not be made without obtaining explicit permission to do so from the person in charge of the work. 
PROJECT 401

\title{
EXAMINATION OF FAST REACTOR FUELS
}

\author{
Person in Charge: $\quad R$. D. Baker \\ Principal Investigators: J. W. Schulte \\ K. A. Johnson \\ G. R. Waterbury
}

\section{INTRODUCTION}

This project is directed toward the examination and comparison of the effects of neutron irradiation on LMFBR Program fuel materials. Unirradiated and irradiated materials will be examined as requested by the Fuels and Materials Branch of NRDT. Capabilities are established and are being expanded for providing conventional preirradiation and postirradiation examinations. Nondestructive tests will be conducted in a hot cell facility specifically modified for examining irradiated prototype fuel pins at a rate commensurate with schedules established by DRDT.

Characterization of unirradiated and ircadiated fuels by analytical chemistry methods will continue, and additional methods will be modified and mechanized for hot cell application. Macro- and micro-examinations will be made on fuel and cladding using the shielded electron microprobe, emission spectrograph, radioch mistry, gamma scanner, mass spectrometers, and other analytical facilities. New capabilities will be developed in: gamma scanning, analyses to assess spatial distributions of fuel and fission products, mass spectrometric measurements of burnup and fission gas constituents, chemical analyses, and measurement of cartion in irradiated fuels.

Microstructural analyses of unirradiated and irradiated materials will continue using optical and electron microscopy, and autoradiographic and $x$-ray techniques. Special emphasis will be placed on numerical representation of microstructures and its relationship to fabrication and irradiation parameters. New etching and mounting techniques will be developed for high burnup materials.

\section{EQUIPMENT DEVELOPMENT}

A. Inert Atmosphere Systems

(P. A. Mason, E. O. Quintana)

The shaft seals on the recirculating pump of the Disassembly Cell purifier deteriorated during September r $\mathrm{r}$ quiring isolation of the unit from the cell. An inert atmosphere has been maintained by an $\mathrm{Ar}$ once-through purge'. Typical concentrations of $<10$ ppm $\mathrm{O}_{2}$ and $<5$ ppm $\mathrm{H}_{2} \mathrm{O}$ are being maintained with a $60 \mathrm{cfh}$ purge. Replacement seals have been procured, with installation expected to be completed by October 13.

The "DTA Cell" was "inerted" over the weekend of September 24 to permit the introduction and handling of sodium. Typical concentrations of $<25 \mathrm{ppm} \mathrm{O}_{2}$ and $<10$ ppm $\mathrm{H}_{2} \mathrm{O}$ were achieved.

Reduction of the air leak rates to the metallography cells was achieved by the installation of Model " $L$ " Manipulators. Concentrations of $<25 \mathrm{ppm} \mathrm{O}_{2}$ and $<10 \mathrm{ppm}$ $\mathrm{H}_{2} \mathrm{O}$ have been obtained on occasions. The large flow rates through the "slurper" solvent disposal system have, on several occasions, exceeded the makeup flow rate capability of the alpha-box pressure differential control system, resulting in excessive negative pressure in the alpha-box. The neisative pressure dropped to the level where air was admitted through the oil trapped, over-pressurization protection device. A modification of the makeup Ar gas flow control system to permit higher flow rates was made, and 
instructions were given to the cell ops rators regarding the proper use and control of the "slurper" system.

Preliminary evaluation testing has begun on the recently purchased Vacuum/Atinospheres MO-40 Gas Purifier System. The unit is being prepared as a mobile backup purifier to the present recirculating purifier units and for temporary installation at other inert cells as required.

\section{B. Manipulator Miaintenance}

Considerable difficulty is being encountered with the frequent "breakdown" of Model "L" manipulators. An average of one manipulator repair per week has been required during this report period. The load capacity of this type manipulator is approximately on $\epsilon$-third that of the AMF Standard Duty Model 8 manipulators.

Some in-cell equipment has been modified to reduce the manipulator force requirements. Careful use of the manipulators by Operators has also been stressed.

An additional PaR Motion Mini-Manipulator was received in August along with a number of spare parts needed for proper maintenance.

C. Fuel Fin Handling System for betatron Radiography (C. D. Montgomery, T. Romanik, J. R. Trujillo)

Shop fabrication of the handling mechanism is now complete, and it is in operational chect--out phase prior to final installation. Sone delay was experienced in delivery of the ball screw assembly and the pneumatic tire wheels.

All components of the new shielded radiography cask were fabricated and inspection has been completed. Final assembly will start the first week of October 1972 . It is anticipated that this cask will be ready for local use by the middle of November.

A special indexing base in the concrete floor of the Betatron building to provide exact positirning of the cask for radiography of fuel pins will also ie completed by midNovember.

Work is still in progress to obtain Special DOT appr val for using this cask as an off-site shipping container. D. Cask Insert, Elevator

(J. M. Ledbetter, C. D. Montgomery,

D. C. Maestas, J. B. Weber)

The second Rover Cask insert elevator was completed and tested in operation with a 275-1b load. It has since been used satisfactorily in loading and unloading fuel from a Rover Cask.

E. Butyl Acetate Removal System

(G. S. Dow, M. E. Irazarus, P. A. Mason)

All of LASL's work has been completed on this system, and a job order has been submitted to the crafts for the remainder of work and installation of the system.

F. Storage Jib for 25-Ton Cask Sling

(C. D. Montgomery, 'i. Romanik, J. R. Trujillo)

A special jib crane for storing the 25-ton, four-

branch sling used to lift the 21-ton Rover Casks at the DP West Facility has been designed. This device will receive the sling from the hook of the 25-ton hoist and swing it out of the way when not in use. It will also deliver the sling to the hoist hook as needed through manual manipulation.

This item will be completed and installed by midNovember.

G. In-Cell Equipment

(M. E. Lazarus, T. Romanik)

1. Optical Gauge for Diameter Mea :urement.

The modification of the B and L DR25B optical gaugc has been completed and preliminary tests indicate that the system works properly. Installation of the gauge at the DP-West Facility is now in progress.

2. Fuel Element Length Gauge. Therroocouple systems have been designed which allow temperature measurements of fuel elements with 300 series stainless steel claddings as well as other cladding materials.

The gauge is constructed of 304 stainless steel and can measure materials with the same coefficient of expansion without requiring tamperature corrections, provided the material and the gauge are at the same temperature.

3. Mechanical Profilometer. The mechanical profilometer will be used primarily for breached fuel elements. Since it may have a low use rate, the replacement profilometer will have only a few modifications over th:one previously installed in the Disassembly Cell. The new unit, which is now under construction, will allow easier maintenance and will eliminate bow error, if required, by physically aligning the fuel element. Construction is now $50 \%$ complete.

4. Electro-Optical Profilometer. A new ElectroOptical unit has been ordered which should completely 
eliminate the error produced when the fuel element moves off center. This unit puts out a digital signal directly instead of an analog signal. The advantage of a dirent digital signal is that the noise level is much lower than in an analog system. Since the repair time on the old unit could be as much as 4 to 6 months, it wi": be regarded as a spare when the new unit has been installed.

\section{Macrophotography. The marrophotography} system is ready for use. However, it will be modified to include placing more legible numbers on the fuel element position device to indicate position along the length. This will aid in improved documentation on the photographs.

\section{MICROSTRUCTURAL ANALYSIS}

(J. H. Bender, D. D. Jeffries, K. A. Johnson

J. L. Lehmann, H. D. Lewis, K. L. Walters)

\section{A. Etching}

Ion gul etching is still being tested for maximation of etching conditions and ror remote operation.

\section{B. Invage Analyses}

Several modifications have been incorporated into the CDC 7660 computer program IMAGE to provide output formats which are suitable for direct transmittal of reduced QTM image analysis data to the experimenter. The new modules acquired for she Quantimet have made possible several aciditional modes of image analysis, one of these being the measurement of the sample distribution of sizes of planar areas. Examination of the standard Saltykov method for analysis of this type of data has led to the development of more general methods for practical data analysis. A detailed discussion is being prepared for journal publication.

\section{INSTALLATION OF AUTOMATIC PHOTOGRAPHIC EQUIPMENT \\ (P. W. Montoya, L. A. Waldschmidt)}

The new automatic Kodak processor and printer have been installed. Testing and servicing by Kodak Engineers will be completed by November 10 at which time LASL will assume responsibility for operating the equipment.

A Techniciarı was sent to the Kodak Training Center in Rochester, N.Y., for a training program in the use and raaintenance of the specialized Kodak $5 \mathrm{~B}-\mathrm{K}$ Printer.

\section{HOT CELL FACILTSY AT DP-WEST}

(M. E. Lazarus, C. D. Montgomery, J. R. Trujillo)

The DP-West Hot Cell Facility is now considered operacionas. Any future reporting of modification to equipment and building services will be listed in pertinent sections of the Quarterly Reports. A view of the Operating $\Lambda$ rea after installation of equipment is shown in Figure 401-1.

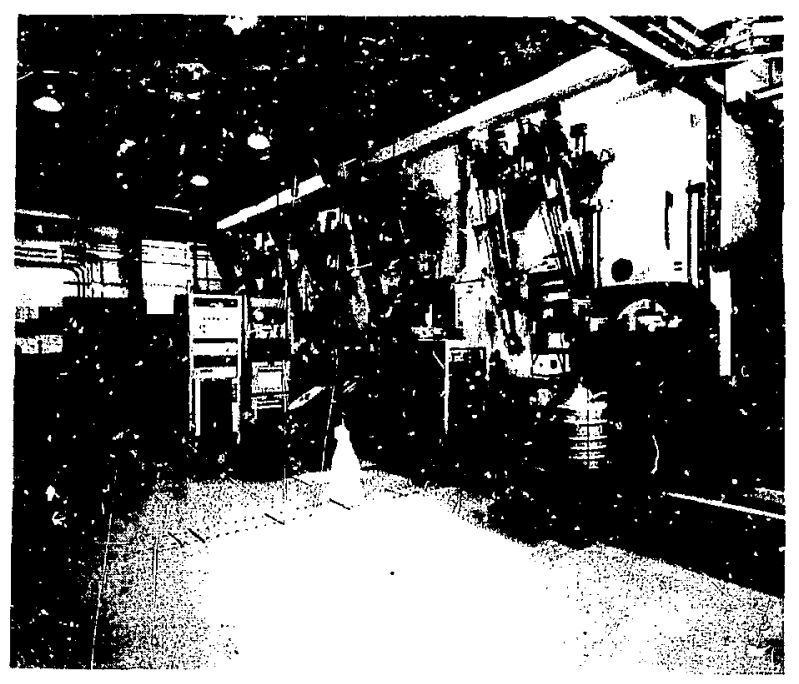

Fig. 401-1. View of Operating Area at the DP-West Facility

\section{ANALYTICAL CHEMISTRY}

\section{1._Gamma Scanning.}

(J. R. Phillips, G. H. Mottaz, J. N. Quiniana, J. R. Netuschil)

a. Two-Dimensional Radial Isotopic Distributions.

Nondestructive gamme scanning was used to determine the two-dimensional, radinl isotopic distributions of three fission products at three axial locations in an irradiated fuel pin containing $(\mathrm{U}, \mathrm{r} u) \mathrm{O}_{2}$ fuel. The distributions of ${ }^{106} \mathrm{Rh}$, ${ }^{137} \mathrm{Cs}$, and ${ }^{95} \mathrm{Zr}$ were determined at each axial position by scanning the fuel pin at $0^{\circ}$ and $90^{\circ}$, and unfolding the data using the TWODIM computer code. ${ }^{1}$ The computer code accepts one or more diumetral scars t ent angles around the outside of the fuel pin and determines the distribution of the measured isstope over the cross section. The results of these measurements serve as an example of the type of information obtainable by tlis relatively new technique. 
The diametral isutopie distribution of ${ }^{106} \mathrm{Rin}$ shown at. the top of $\mathrm{Fig}$. 401-2 was used to generate the rensity plot shown in the bottom of the figure. Similarly, the typieal diametral distributions of ${ }^{137} \mathrm{Cs}$ and ${ }^{95} \mathrm{Zr}$ with their curresponding density' plots are showr in Figs. 401-3 and $401-4$, respertively. The ${ }^{95} \mathrm{Zr}$ distribution also is presented as an isometric projection in Fig. 401-5.
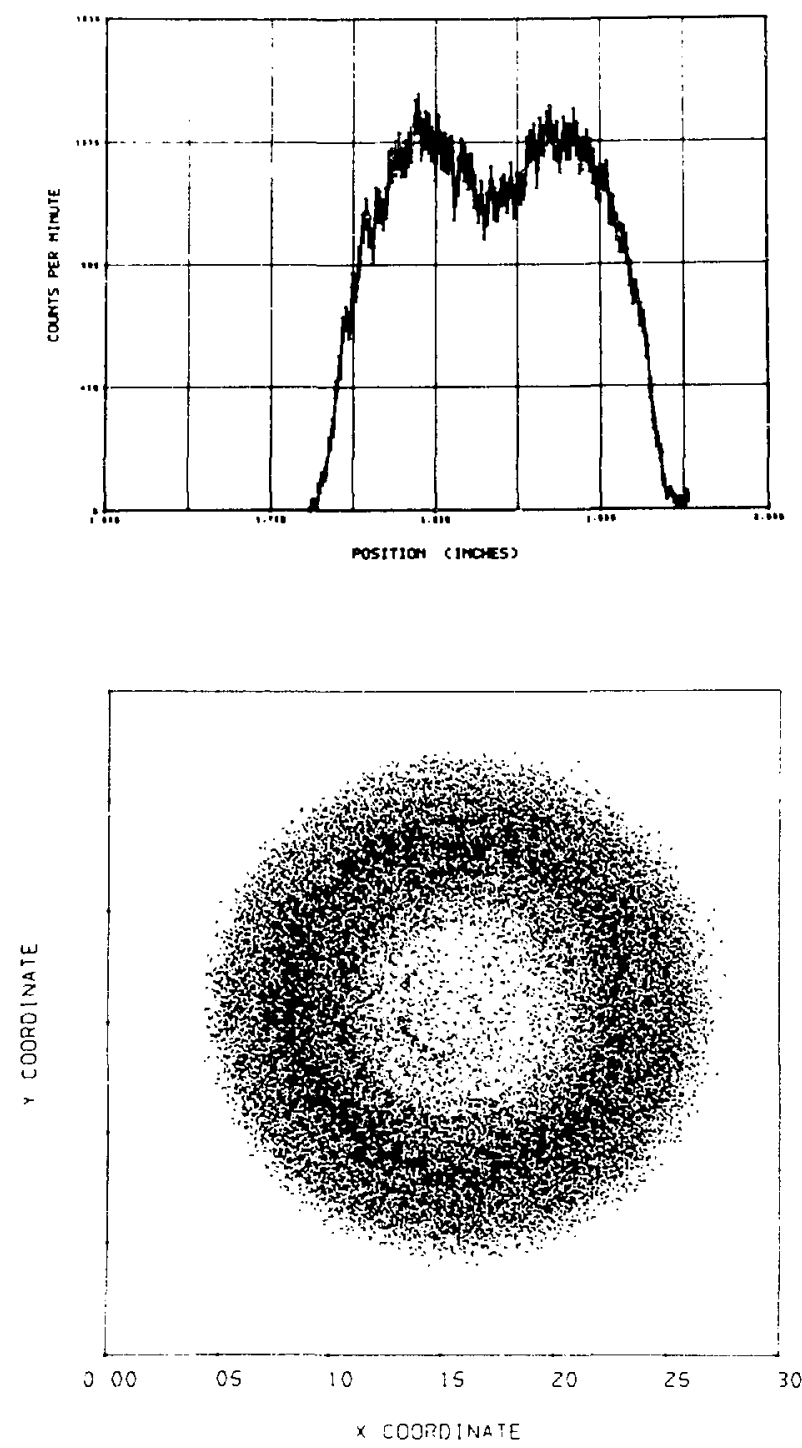

Fig. 401-2. Mrasured ${ }^{106}$ Rh diametral isotopic distribution (Top) used to calculate two-dimensional isotopic distribution (Bottom).
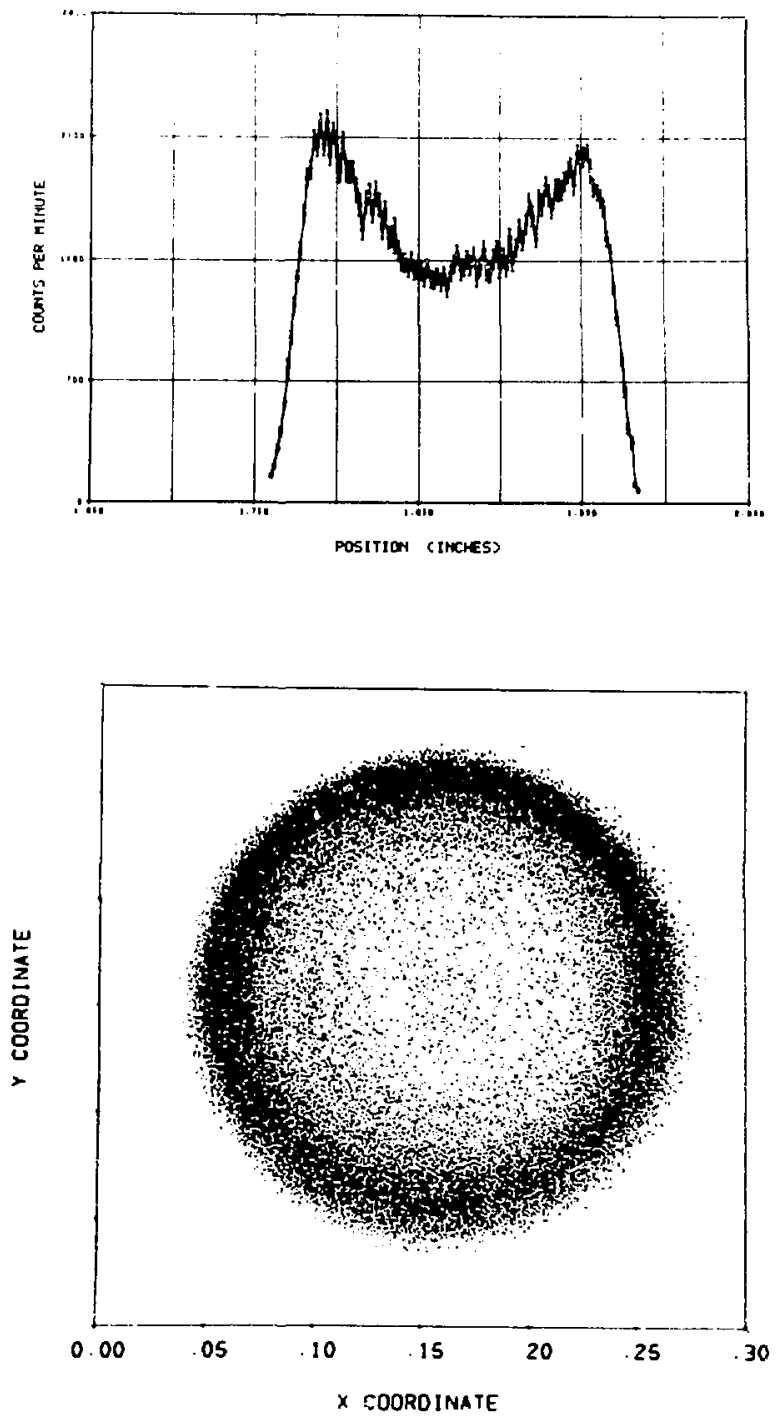

Fig. 401-3. ${ }^{137} \mathrm{Cs}$ diametral isotopic distribution (Top) with two-dimensional isotopic distribution (Bottom).

From these examples can be deduced the probable migrations of these three fission products which were chosen because of their different properties. The ${ }^{106} \mathrm{Rh}$ (Figure 401-2) concentrated radially between the central void and the columnar grain boundary. The ${ }^{137} \mathrm{Cs}$ migrated radially, concentrating near the outer surface. The ${ }^{95} \mathrm{Zr}$ remained with the fuel material, showing the relative position of the fuel. This nondestructive technique does not 

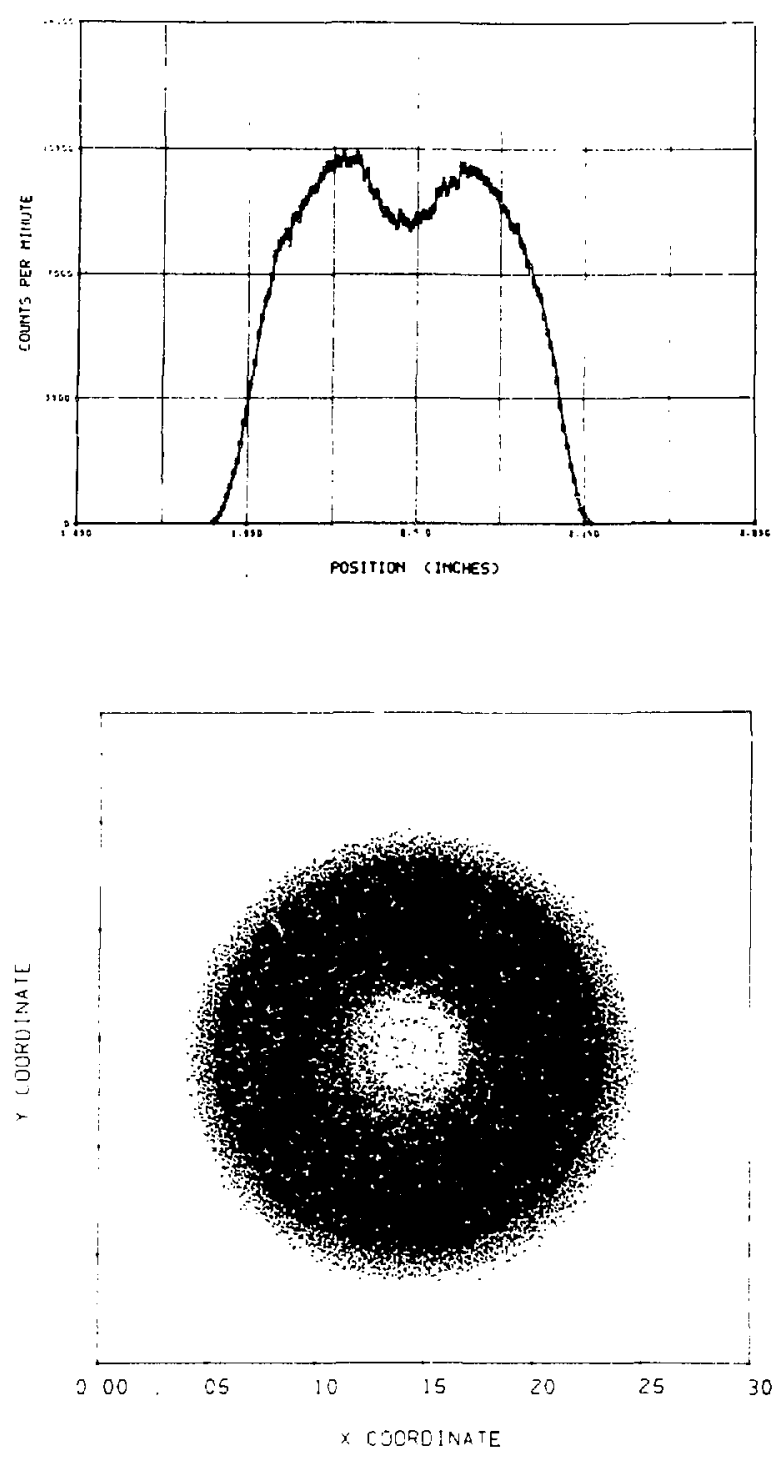

Fig. 401-4. ${ }^{95} \mathrm{Zr}$ diametral isotopic distribution (Top) with two-dimensional isotopic distributions (Bottom) .

require sectioning of the sample to provide the two-dimensional isotopic distributions of fission products in irradiated fuel pins.

b. Equipment at DP West. The DP West computer-controlled, gamma scanning system is in operation, having scanned six fuel pin sections. The data processing computer code, SURVEY, was modified, by incorporating additional plotting routines, to increase data manipulation capabilities.

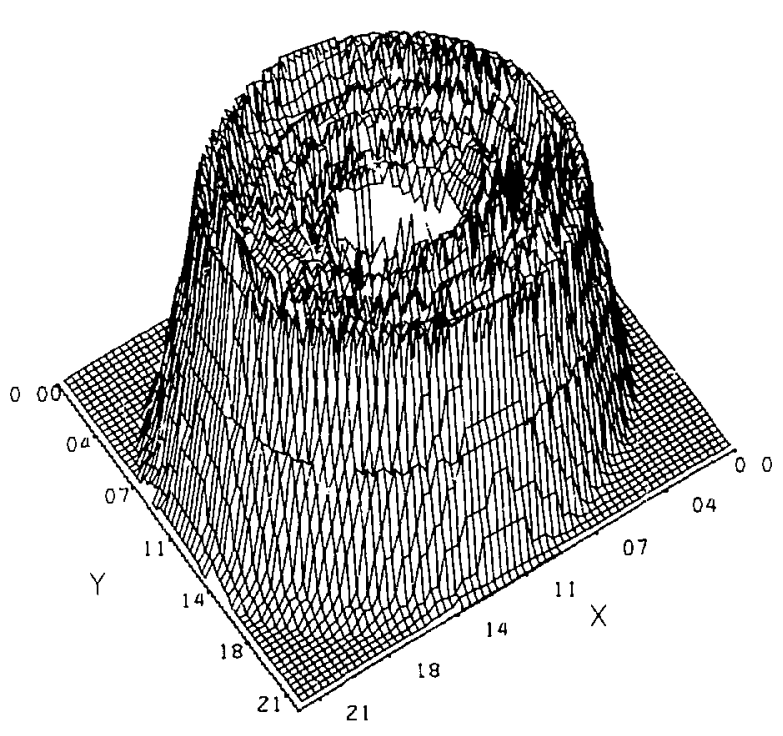

ZR $95 \quad 724$ KEV $25995 \quad$ IN

Fig. 401-5. Isometric projection of the ${ }^{95} \mathrm{Zr}$ isotopic distribution shown in Fig. 401-4.

2. Determination of $U$ and $P u$ in Irradiated Fuels. (J. W. Dahlby and R. R. Geoffrion)

Controlled-potential coulometry provides the capability to measure $\mathrm{U}$ and $\mathrm{Pu}$ without chemical separation from each other in solutions of irradiated $(\mathrm{U}, \mathrm{Pu}) \mathrm{O}_{2}$ fuels. The $\mathrm{U}$ is measured by integrating the current while reducing U(VT) to U(IV), and subtracting a blank obtained by again reducing the same sample after a 6-min waiting period. The $\mathrm{Pu}$ is determined by integrating the current to oxidize $\mathrm{Pu}(\mathrm{II})$ electrolytically to $\mathrm{Pu}(\mathrm{IV})$ and then reducing the $\mathrm{Pu}(\mathrm{IV})$ to $\mathrm{Pu}(\mathrm{III})$. This oxidation-reduction cycle is repeated until successive integrated currents agree within $2 \mathrm{mV}$ or $2 \mu \mathrm{g}$ of $\mathrm{Pu}$. Neither separation of the $\mathrm{U}$ and $\mathrm{Pu}$ from each other nor from the fission products is required for samples having up to $6 \%$ burnup. Small samples containing approximately $1 \mathrm{mg}$ of fuel can be analyzed for $\mathrm{U}$ and $\mathrm{Pu}$ with a precision of $0.5 \%$ relative standard deviation.

'Tlt' analysis of fuels having burnups greater than $6 \%$ is adversely affected by the increased radioactivity and fission products. Because of this, a separation of the $\mathrm{U}$ and $\mathrm{Pu}$ from the highly radioactive fission products is 
being investigated. Precipitation separations are quick and easy to perform under remote conditions so they are being investigated. In the most promising precipitation separation method, the $U$ and $P u$ are precipitated with $\mathrm{NH}_{4} \mathrm{OH}$, filtered, and the $\mathrm{U}$ is selectively dissolved in a basic solution of $\mathrm{NH}_{2} \mathrm{OH}$. Greater than $95 \%$ of the $\beta-\gamma$ active fission products were removed from the $U$ usins this separation scheme. Recoveries of $U$ were $99.6 \%$. Most of the $0.4 \%$ loss was caused by a small amount cf $U$ (< $1 \mathrm{mg}$ of the original $200 \mathrm{mg}$ of $\mathrm{U}$ ) not dissolved by the $\mathrm{NH}_{2} \mathrm{OH}$ when $\mathrm{Pu}$ is present. The $\mathrm{U}$ is quantitatively dissolved if Pu is absent.

Several teciniques are being tried to improve the dissolution and recovery of $U$ without reducing the fission product removed. Oniy slight improvement in the U recovery from $99.6 \%$ to 99.7 to $99.8 \%$ has been attained.

\section{REQUESTS F FOM DRDT}

\section{A. Examination of Unirradiated Fuei Pins}

(M. E. Lazarus)

Measurements vere made on the Optical Profilometer of 20 BiMI and 7 ORNL fuel pins. These pins are being followed by LASL personnel.

\section{B. Examination of Irradiated Materials}

(R. N. Abernathey, K. A. Johnson, M. E. Lazarus,

R. A. Morris, J. R. Phillips, J. W. Sehulte,

G. R. Waterbury, W. F. Zelezny)

General Electric Company: Examinations performed on irradiated fuel 9 ssemblies received on February 14,1972 are tabulated in Table 401-I.

\section{TABLE 401-I}

POSTIRRADIATION EXAMINATIONS OF PINS FROM GE

\begin{tabular}{ll}
\multicolumn{1}{c}{ Fxamination } & \multicolumn{1}{c}{ Pin Identity } \\
Sectioning & F12P, F12Q, F4A, F4E \\
Photography (Sectioned Faces) & F4A, F4E \\
Length Me-asurement & F4A, F4E \\
Density of Pin Claclding & F4A, F4E, F9C-13
\end{tabular}

Fuel and clad :specimens from GE-F9C-13, GE-F4A, and GE-EAE were dissolved, and burnup measurements were madu.

The shielded electron microprobe was used for $\mathrm{ex}-$ amining a cross -section sample of GE-F9C-13 (F).
Three clad samples from each fuel pin (GE-F9C-13, $G E-F 4 A$, and $G E-F 4 E$ ) were cleaned and prepared for density measurement.

Microstructural examinations consisting of macrophotography, alpha and beta-gamma autoradiography, and optical microscopy (including mosaics) were carried out in an Ar atmosphere on specimens as listed in Table $401-\Pi$.

TABLE 401-II

MICROST RUCTURAL ANALYSIS OF GE MATERIALS

\begin{tabular}{lcccc} 
GE Pin No. & $\begin{array}{c}\text { No. Samples } \\
\text { Futl and Clad }\end{array}$ & \multicolumn{2}{c}{$\begin{array}{c}\text { Section Type } \\
\text { Longit. or Transverse }\end{array}$} \\
GE-F9C-13 & 2 & & $1 \mathrm{~L}$ & $1 \mathrm{~T}$ \\
GE-F4A & 2 & $1 \mathrm{~L}$ & $1 \mathrm{~T}$ \\
GE-F4E & 2 & $1 \mathrm{~L}$ & $1 \mathrm{~T}$ \\
GE-F 12P & 3 & $2 \mathrm{~L}$ & $1 \mathrm{~T}$ \\
GE-F 12Q & 3 & $2 \mathrm{~L}$ & $1 \mathrm{~T}$
\end{tabular}

Two samples were also prepared for electron microprobe including pre- and post-EMX photomicroscopy. Three samples were also analyzed using imate analyses; these reports are in progress.

Gulf United Nuclear Fuels Corporation: Examinations of irradiated fuel pins received February 22, 1972 are tabulated in Table 401-III.

Hanford Engineering Development Laboratory: Examinations of irradiated fuel pins received February 22, 1972 are tabulated in Table 401-rV.

TABLE 401-II

POSTIRRADIATION EXAMNATION OF GU MATERIAL

$\begin{array}{ll}\frac{\text { Examination }}{\text { Profilometry (Electro-Optical) }} & \text { UNC-138, UNC-146 } \\ \text { Photography } & \text { UNC-194 } \\ \text { Eddy Current } & \text { UNC-194t }\end{array}$

TABLE 401-IV

POSTIRRADIATION EXAMTNATIONS OF PINS FRUM HEDL

\begin{tabular}{ll}
\multicolumn{1}{c}{ Examination } & \multicolumn{1}{c}{ Pin Identity } \\
Profilometry (Electro-Optical) & P-17A-5, $-19,-20$, \\
& $-29,-31$ and -33 \\
Sectioning & P-17A-16, -17, -19, \\
& -20 and -27
\end{tabular}

Gamma scanning, including 7 gross and 6 complete spectral :scan:s, was applied to the nondestructive 
examination of HEDL-P17A-16. Also on this same fuel pin, radial isotopic distrivutions of ${ }^{106} \mathrm{Rh},{ }^{137} \mathrm{Cs}$, and

${ }^{95} \mathrm{Zr}$ were determined at 3 axial positions using the TWODIM computer code to unfold the individual fission product distributions.

Cross-section samples from HELL-P-17A-16 (H), HEDL-P-17A-2 (D), and HEDL-P-17A-26 (B) we re examined using the shielded electron microprobe.

A cross-section sample of fuel and clad from HEDL -P - 17A-27 was dissolved and analyzed for burnup.

Microstructural examinations consisting of macrophotography, alpha and beta-gamma autoradiography, and optical microscopy (including mosaics) were carried out in an Ar atmosphere on specimens as listed in Table 401-V.

TABLE 401-V

MICROSTRUCTURAL ANALYSIS OF HEDL MATERIALS

\begin{tabular}{|c|c|c|c|}
\hline HEDL Pin No. & $\begin{array}{l}\text { No. Samples } \\
\text { Fuel and Clad }\end{array}$ & \multicolumn{2}{|c|}{$\begin{array}{c}\text { Section Type } \\
\text { Longit. or Transverse }\end{array}$} \\
\hline HEDL-P17A-18 & 5 & $2 \mathrm{I}_{\Delta}$ & $3 T$ \\
\hline HEDL-P17A-26 & 3 & $2 L$ & $1 \mathrm{~T}$ \\
\hline HEDL-P17A-27 & 3 & $2 L$ & $1 \mathrm{~T}$ \\
\hline
\end{tabular}

Three samples were also prepared for electron microprobe including pre- and post-EMX photomicroscopy.

Los Alamos Scientific Laboratory: The fuel was removed from 2 fuel-clad sections of pin $42-\mathrm{B}$. The clad sections were processed in the metallography cells. The resulting polished specimens, in 1.25-in. mounts, will be shipped to ANL-En:i for examination.

Oak Ridge National Laboratory: The fission gas from ORNL $-43-\mathrm{N} 2-1,-2,-3$, and -4 was analyzed mass spectrometrically.

Other Material From Experimenters: The schedule for examining materials at LisL indicates that approximately 134 pins will be reseived by May 1, 1973 . Th is listing was determined after discussions with Sponsors from ANL, GE, HEDL, and LASL. Distribution of the pins is iabulated in Table 401-VI.

This partial list of pins may be modified by changes in EBR-II Reactor Schedule, priority adjustments by RDT, or changes in plans of the various Experimenters.
TABLE 401-VI

FUEL PINS TO BE EXAMINED AT LASL DURING FY 1973-1974

\begin{tabular}{|c|c|}
\hline Sponsor & No, of Pins \\
\hline ANL & 1 \\
\hline GE & 11 \\
\hline HEDL & 84 \\
\hline LASL & 38 \\
\hline & 134 \\
\hline
\end{tabular}

VIII. PUBLICATIONS, TALKS

1. C. D. Montgomery, M. G. Chavez, M. E. Lazarus, "Development of Ancillary Equipment for Usc in Hot Cell Facilities, "Proceedings of the 20 th Conference on Remote Systems in Technclogy, American Nuclear Society, 331 (1972).

2. D. D. Jeffries, J. H. Bender, and K. A. Johnson, "Improvements in Remote Metallography in Incrt Atmospheres, " Proceedings of the 20th Conference on Remote Systems Technology, American Nuclear Society, 143 (i972).

3. J. R. Phillips, G. R. Waterbury, G. H. Mottaz, and J. N. Quintana, "New Systems for Gamma Scanning Fuel Elements," Proc. 20th Remote Sỵstems Technology, American Nuclear Society, 115 (1972). Also presented as a talk at the meeting, Idaho Falls, ID, September 19-21, 1972 .

4. C. S. MacDougall, M. E. Smith, and G. R. Waterbury, "Remotized Apparatus for Determining Oxygen in Irradiated Reactor Fuels and Cladding Materials." Presented at the 20th Conference on Remote Systems Technology, American Nuclear Society, Idaho Falls, DD, September 1921,1972

\section{REFERENCES}

1. B. K. Barnes and J. R. Phillips, "TWODIM, A Computer Code for Unfolding Diametral GammaRay Scans on Reactor Fuel Elements," Los Alamos Scientific Laboratory Report LA-4676 (May 1971).

\section{CORRECTION -- PROJECT 401}

In LA-5067-PR, p. 8, left-hand column, 2nd sentence, should read as follows: "To determine if the cesium activity could be related to the oxygen contents of the specific pellets, analyses were made for total oxygen in pellets having high cesium activity and in pellets with low cesium activity. The preliminary results showed that the cesium activity was directly related to the oxygen contents." 
PROJECT 463

HIGH PERFORMANCE '. MF BR FUEL MATERIALS

Person in Charge: R. D. Baker

Principal Investigator: J. L. Green

\section{I . INT RODUCTION}

The primary objective of this prograw is the overall evaluation of the most promising of the candidate fuel systems for advanced LMF BR application. Emphasis currently is placed on the study of the relative merits of stainless steel clad nitride and carbide fuels under conditions that appropriately exploit the potential of these materials to operate to high burnup at high power densities. The major portion of the program is the evaluation of the irradiation performance of these fuel element systems. A continuing series of irradiation experiments is being carried out under steady state conditions in fast reactor environments to assess the effects of damage and burnup on stainless steel clad, carbide and nitride fuel elements. These experiments are designed to investigate fuel swelling, interactions between the fuel and clad and thermal bonding medium, fission gas release, and the migration of fuel material and fission products as a function of burnup and irradiation conditions. In addition, experiments are being designed to allow the study of the effects of rapid, overpower, reactor transients on car bide and nitride fuel assemblies. Contiguous efforts are necessary in the development of fuel material preparation and fabrication procedures as well as the techniques required for the characterization of fuel materials both before and after irradiation.

A second objective in the program is the determination of thermophysicl, mechanical and chemical properties and charscteristics of plutonium-containing cerarıics that are required for their evaluation and use as fuel materials. A broad range of capabilities in this area has been developed, including the study of (1) phase relationships using differential thermal analysis, (2) thermal transport, (3) thermal stability and compatibility, (4) hot hardness and its temperature dependence, (5) structure and phase relationships using high temperature $x$-ray and neutron diffraction, (6) thermal expansion, and (7) compressive creep rates as a function of temperaturc and stress. Several of these techniques are available for use with irradiated fuel.s.

\section{IRRADIATION TESTING}

The objective of the irradiation testing program is the overall evaluation of the most promising of the candidate fuel systems for advanced LMFBR application. The irradiation experiments are carried out under conditions that take advantagc of the potential of these materials to operate to high burnup at high power densitjes.

A. Synthesis and Fabrication

(K. W. R. Johnson, H. Moore, C. Baker, R. Walker, C. W. Bjorklund, and J. G. Reavis)

1. Carbide Production. Quality Assurance requirensents make it necessary to have complete fuel specifications before pellets can be produced. Dimensional parameters for upcoming EBR-II and Treat experiments have not been finalized; hence, no fuel pellets have been produced. At the time the QA program was put into effect, four batches of pellets were in process. Of these four batches, two were in the form of annealed ingots which are being stored for future use. One batch of $\mathrm{H}_{2}$ treated powder was stored in a vacuum sintering furnace. This 
material deteriorated due to repeated removal of the powder from the system when it was neccssary to use the furnace for other purposes. A second batch of $\mathrm{H}_{2}$ treated powder was stored in a vacuum-tight container. This material was sampled for $\mathrm{O}_{2}$ after a period of 3 months and it was found to contain $\doteq 75$ ppm.

2. Process Development

a. Carbide Production by Carboihermic Reduction of $\mathrm{UO}_{2}-\mathrm{PuO}_{2}$

Deveiopment of the carbothermic reduction

process for production of pure (low oxygen), single phase $\mathrm{U}_{0.8} \mathrm{Pu}_{0.2} \mathrm{C}$ is continuing. The steps used in this process are:

1. Bali mill and blend $\mathrm{UO}_{2}, \mathrm{PuO}_{2}$ and excess graphite.

2. Form low density powder compacts,

3. Heat in vacuum at $1400-1700^{\circ}$ until $\mathrm{CO}$ evolution ceases,

4. Crush and comminute,

5. Heat in flowing $\mathrm{H}_{2}$ at $800^{\circ} \mathrm{C}$ to remove higher carbide,

6. Press to form fuel pellets,

7. Sinter under Ar.

It was reported previously ${ }^{1}$ that $\mathrm{U}_{0.8} \mathrm{Pu}_{0.2} \mathrm{C}$ containing acceptably low oxygen concentrations we re prepared on the $50 \mathrm{~g}$ scale. Recent experiments have been run to demonstrate the process on the $250 \mathrm{~g}$ scale. These experiments have also had as their aims the optimization of carbon concentration in the oxide-graphite mixture, and selection of optimum reaction conditions.

Historically, the two most serious problems encountered in the preparation of single-phase monocarbides using established carbothermic reduction techniques have been high oxygen concentrations in the product and the control of the carbon content of the product. This new procedure has been devised to eliminate these two problems. The uniquc features of the LASL process are:

1. The initial oxide-carbon mixture is intentionally made carbon rich to ensure the presence of sesquicarbide in the reduction product. This is done to maintain a large carbon activity during the final stages of the reduction.
2. The final high temperature stage of the carbothermic reduction step is carried out in high vacuum. This is critical to the preparation of material having low residual oxygen contents.

3. The use of the LASL hydrogen reduction procedure to remove all higher carbides from the pruduct.

Carbon concentrations used and results of analyses of the products of some of these experiments are listed in Table 463-I. Comparison of the data from experiments $C R-8$ and $C R-9$ seems to show that a trade-off must be made between oxygen concentration and $\mathrm{M}_{2} \mathrm{C}_{3}$ concentration in the reduction product, and that these concentrations can be effectively regulated by varying the graphite content of the original mixture. The results of CR-10 show that low oxygen concentrations can be maintained in the product when the process is operated on the $250 \mathrm{~g}$ scale. The difference in procedure believed to account for the differences in oxygen concentrations of the products of $\mathrm{CR}-10$ and $\mathrm{CR}-11$ is that Batch CR-10 was held at $1700^{\circ}$ for 130 min during reduction, while Batch C-11 was held at $1700^{\circ}$ for $110 \mathrm{~min}$.

The product of CR-10 was taken through the remaining steps of the process. The fuel pellets produced contained tranes ( $<1$ vol\%) of platelets which indicated that a somewhat longer $\mathrm{H}_{2}$ reduction treatment is needed.

The oxygen concentration in the final pellets was $330 \mathrm{ppm}$. The product of reduction CR-11 has not yet ieen taken through the final steps of the process.

TARLE 463-I

SLMMARY OF RECENT CARBUTHERMI REDLCTIONS FOR PRODLCTION OF $\mathrm{v}_{0.8} \mathrm{Pu}_{0.2} \mathrm{C}$

\begin{tabular}{|c|c|c|c|c|}
\hline $\begin{array}{c}\text { Experiment } \\
\text { No. } \\
\end{array}$ & $\begin{array}{r}\text { Batch } \\
\text { Size, g } \\
\end{array}$ & $\begin{array}{l}\text { Original } c \\
\text { Conc, ut } \\
\end{array}$ & $\begin{array}{c}\text { O in } \\
\text { Product, pym } \\
\end{array}$ & $\begin{array}{l}\mathrm{MI}_{2} \mathrm{C}_{3} \text { In } \\
\text { Product, vol }\end{array}$ \\
\hline$C K-8$ & 50 & 12.12 & 30 & $\sim 15$ \\
\hline CR -9 & 50 & 11.92 & 475 & $<$ \\
\hline CR-10 & 250 & 11.99 & 10 & 5 \\
\hline$C R-12$ & 250 & 21.99 & 290 & $\sim 5$ \\
\hline
\end{tabular}

Proslust fron the carbothermic reduction step. 
b. Pellet Production and Characterization. The density specification for carbide fuel for the Series $\mathbf{K 4}$ tests has been set at $95 \pm 2 \%$ TD. Batches 37 and 38 were 92.9 and $92.5 \%$ TD. Both batches were resintered at $1850^{\circ} \mathrm{C}$ for $8 \mathrm{~h}$ and then at $1400^{\circ} \mathrm{C}$ for $2 \mathrm{~h}$. The densities increased to 95.0 and 94.0 , respectively, with no alteration in the chemical composition. Other batches which have densities below the specification are being resintered.

During the examination of a storage container of archival fuel it was observed that three adjacent pellets showed evidence of deterioration. This material was subjected to chemical and microstructural analysis. The chemical analysis indicated that oxygen wes the only contaminant which was present in a larger amount (0.16 wt\%) than that reported for the as-fabricated pellets. Microstructural analysis showed a structure replete with microcracks, typical of room temperature oxidation. Further investigations are being carried out in an attempt to identify the source of the contaminant.

3. Equipment Development. A furnace similar to the new hydrogen treatment furnace ${ }^{1}$ was installed in the nitride preparation glovebox. Each of these furnaces, when heated in an inert atmosphere caused an excessive temperature increase inside of the glovebox. The furnace heat loss was decreased substantially by adding insulation to the furnace. It was observed that after insulating the furnace in the nitride glovebox the atmosphere temperature $r>$ mained at an acceptable level. The atmosphere recirculation unit for this glovebox incorporates a water cooled heat exchanger which provides sufficient cooling to maintain the glovebox temperature at an acceptable level during furnace operation. A similar heat exchanger is being installed in the glovebox housing the $\mathrm{H}_{2}$ treatment furnace.

A high temperature, tungsten mesh, resistance hisated, sintering furnace is being installed in a recirculatùng, inert atmosphere glovebox. The completed installation will provide a temperature capability of $2750^{\circ} \mathrm{C}$ in atmospheres of $\mathrm{N}_{2}, \mathrm{Ar}$, He, $\mathrm{H}_{2}$ or vacuum. Temperature cycles may either be controlled manually or programmed. The furnace has been leak tested and operated at $1400^{\circ} \mathrm{C}$ and $8 \times 10^{-7}$ torr.
In anticipation of the tight fuel pellet diameter tolerances that will be required for fuei elements using close fitting shroud tubes, a centerless $\mathrm{g}$ rinder has been fabricated. An existing, recirculating, inert atmosphere glovebox is being installed to house the grinding operation. The box was previously used for nonradioactive materials, so glove port and exhaust system modifications are necessary to convert it to use with plutonium.

An electronic balance was acquired for use in the fuel preparation facility. Preliminary evaluation indicated that the balance did not meet specifications or the program needs, hence it was returned to the manufacturer for modification and refinement.

\section{Nitride Fuel Pellet Evaluation. A total of} $258 \mathrm{U}_{0.8} \mathrm{Pu}_{0.2} \mathrm{~N}$ pellets comprising four batches of fuel were received from Battelle Memorial Institute. Radiographic examination indicated that 170 pellets we re either cracked or chipped. Further chacterization will be carried out after the BMI QA documentation is received for this material.

B. EBR-II Irradiation Testing

(J. O. Barner, T'. W. Latimer, L. L. Marriott, H. E. Strohm)

The purpose of the EBR-II testing program is the evaluation of the steady-state irradiation behavior of high performance fuel element systems for application in advanced LMFBR reactors. Several series of carbide-and nitride-fueled experiments have been initiated in the past several years. The main objectives of the irradiations are: (1) the development of fuel element designs for use with both fuel types; (2) the determination of the irradiation behavior of the fuel materials; (3) a comparison of sodium and helium bonding; (4) a comparison of different cladding alloys; and (5) the evaluation of the overall irradiation performance of the fuel clcment systems. The majority of the experiments under test or that have been completed have been encapsulated. Most of the experiments that are currently available for irradiation or that are being designed are singly clad.

Fourteen series of experiments have been originated. The description and status of these series are summarized in Tables $463-11$ to $463-X I$. 
TABLE 463-II

SERIES K1, K2, AND K3 CARBIDE EXPERIMENTS ${ }^{\mathrm{a}}$

\begin{tabular}{|c|c|c|c|c|c|c|c|c|}
\hline $\begin{array}{c}\text { Experiment } \\
\text { No. } \\
\end{array}$ & $\begin{array}{c}\text { Series } \\
\text { No. } \\
\end{array}$ & Fuel Tyge & $\begin{array}{c}\text { Fuel } \\
\text { Density, } \\
\text { \% T. D. }\end{array}$ & $\begin{array}{l}\text { Diametral } \\
\text { Gap, in. }\end{array}$ & $\begin{array}{l}\text { Max. Fuel } \\
\text { Temp. at } \\
\text { Startup, }{ }^{\circ} \mathrm{C}\end{array}$ & $\begin{array}{l}\text { Max. Linear } \\
\text { Power, Kw/ft }\end{array}$ & $\begin{array}{l}\text { Current } \\
\text { Burnup } \\
\text { at. } \% \\
\end{array}$ & Status \\
\hline $\mathrm{K}-36 \mathrm{~B}$ & 1 & $\left(\mathrm{U}_{0.8} \mathrm{Pu}_{0.2}\right) \mathrm{C}$ & 90 & 0.015 & 1165 & 30 & 6.8 & NUT - out ${ }^{f}$ \\
\hline $\mathrm{K}-37 \mathrm{~B}$ & 1 & $\left(\mathrm{U}_{0.8}{ }^{\mathrm{Pu}}{ }_{0.2}\right) \mathrm{C}$ & 90 & 0.015 & 1165 & 30 & 3.2 & NDT - out ${ }^{c}$ \\
\hline $\mathrm{K}-38 \mathrm{~B}$ & 1 & $\left(\mathrm{U}_{0.8}{ }^{\mathrm{Pu}}{ }_{0.2}\right) \mathrm{C}$ & 90 & 0.015 & 1165 & 30 & 6.4 & $\mathrm{X} 152-$ in $^{\mathrm{d}}$ \\
\hline$K-39 B$ & 1 & $\left(\mathrm{U}_{0.8^{\mathrm{Pu}}} \mathrm{u}_{0.2}\right)^{\mathrm{C}}$ & 90 & 0.015 & 1165 & 30 & 6.4 & $\times 152$ - in \\
\hline $\mathrm{K}-40 \mathrm{~B}$ & 1 & $\left(\mathrm{U}_{0.8^{\mathrm{Pu}}} \mathrm{u}_{0.2}\right)^{\mathrm{C}}$ & 95 & 0.020 & 1150 & 30 & --- & To be built \\
\hline $\mathrm{K}-41 \mathrm{~B}$ & 1 & $\left(\mathrm{U}_{0.8^{\mathrm{Pu}}} \mathrm{u}_{0.2}\right)^{\mathrm{C}}$ & 95 & 0.020 & 1150 & 30 & -- & To be huilt \\
\hline $\mathrm{K}-42 \mathrm{~B}$ & 1 & $\left(\mathrm{U}_{0.8^{\mathrm{Pu}}} \mathrm{u}_{0.2}\right) \mathrm{C}$ & 90 & 0.015 & 1165 & 30 & 5.0 & Completed \\
\hline$K-43$ & 3 & $\left(\mathrm{U}_{0.8} \mathrm{Pu}_{0.2}\right) \mathrm{C}$ & 95 & 0.020 & 1150 & 30 & 6.1 & $x 152-$ in \\
\hline $\mathbf{K}-44$ & 3 & $\left(\mathrm{U}_{0.8} \mathrm{Pu}_{0.2}\right) \mathrm{C}$ & 95 & 0.020 & 1150 & 30 & 6.1 & $X 152-$ in \\
\hline K-45 & 3 & $\left(\mathrm{U}_{0.8} \mathrm{Pu}_{0.2}\right) \mathrm{C}$ & 95 & 0.020 & 1150 & 30 & 3.0 & NDT - out ${ }^{f}$ \\
\hline$K-46$ & 3 & $\left(\mathrm{U}_{0.8} \mathrm{Pu}_{0.2}\right) \mathrm{C}$ & 95 & 0.020 & 1150 & 30 & 2.9 & NDT - out ${ }^{f}$ \\
\hline $\mathrm{K}-47$ & 3 & $\left(\mathrm{U}_{0.8} \mathrm{Pu}_{0.2}\right) \mathrm{C}$ & 95 & 0.020 & 1150 & 30 & $-\infty$ & To be built \\
\hline $\mathrm{K}-48$ & 3 & $\left(\mathrm{U}_{0.8} \mathrm{Pu}_{0.2}\right) \mathrm{C}$ & 95 & 0.020 & 1150 & 30 & --- & To be built \\
\hline$K-49$ & 2 & $\left(\mathrm{U}_{0.8} \mathrm{Pu}_{0.2}\right) \mathrm{C}$ & 95 & 0.020 & 1400 & $45-50$ & 4.0 & NDT - out \\
\hline $\mathrm{K}-50$ & 2 & $\left(\mathrm{U}_{0.8} \mathrm{Pu}_{0.2}\right) \mathrm{C}$ & 95 & 0.020 & 1400 & $45-50$ & 4.0 & NDT - out \\
\hline$K-51$ & 2 & $\left(U_{0.8}{ }^{P u_{0.2}}\right) C$ & 95 & 0.020 & 1400 & $45-50$ & 3.9 & NDT - out f \\
\hline
\end{tabular}

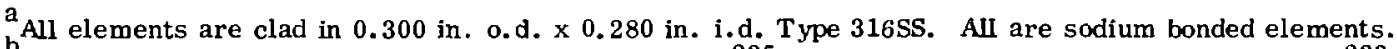

The series 1 and 3 experiments are fully enriched in ${ }^{235} \mathrm{U}$. The series 2 experiments contain $97 \% 233 \mathrm{U}$. All fuel is single-phase.

Capsule K-37B was damaged during reconstitution of X152 to such an extent that it cannot be irradiated further. $\mathrm{d}^{\text {Failure indicated by } \gamma \text {-scan. }}$

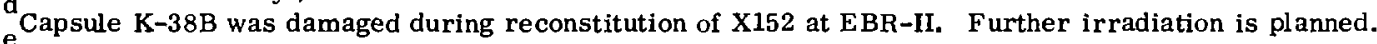

Reported in LA-4669-MS.

F ailure indicated by $\gamma$-scan at EBR-II.

Table 463-II describes the $\mathrm{K} 1, \mathrm{~K} 2$, and $\mathrm{K} 3$ series of tests. In these experiments single-phase, high-purity, uranium-plutonium monocarbide pellets are sodium bonded to Type 316 stainless steel cladding. In general, the operating linear power ratings of the capsules are high (approximately $30 \mathrm{Kw} / \mathrm{ft}$ ). Three tests at very high powe $\mathrm{r}$ $(>40 \mathrm{Kw} / \mathrm{ft})$ were included to determine the effect of high thermal stresses and high fuel temperatures on fuel element behavior. Indications of element failure were found at. KBR-II in several experiments from this group, five in subassembly X119B and one from X142, using $\gamma$-scanning for ${ }^{133}$ Ye. Preliminary examinations of these experiments in the LASL hot cells indicate that the capsules are bowed as much as $3 / 8$ in. Further nondestructive examination of the failed experiments is currently under way.

Table 453-III describes the Series U1300 experiments. These experiments contain two-phase, uraniumplutonium carbide fuel pellets which are helium bonded tc either Type 316 stainitss steel or Incoloy 800 cladding. Two methods for the accommodation of fuel swelling were 
TABLE 460-III

SERIES U1300 CARBIDE EXPERIMENTS

\begin{tabular}{|c|c|c|c|c|c|c|c|c|c|c|}
\hline $\begin{array}{c}\text { Experiment } \\
\text { No. }\end{array}$ & Fuel Type ${ }^{a}$ & $\begin{array}{c}\text { Fuel } \\
\text { Density } \\
\text { \% I.D. }\end{array}$ & $\begin{array}{c}\text { Clad } \\
\text { Material }\end{array}$ & $\begin{array}{c}\text { Clad } \\
\text { Thickness, } \\
\text { in. }\end{array}$ & $\begin{array}{l}\text { Dlametral } \\
\text { Gap, in. }\end{array}$ & $\begin{array}{c}\text { Fuel - } \\
\text { to- } \\
\text { Clad } \\
\text { Bond } \\
\end{array}$ & $\begin{array}{l}\text { Max. Fuel } \\
\text { Temp. at } \\
\text { Startup, } \mathrm{C}\end{array}$ & $\begin{array}{l}\text { Max. } \\
\text { Linenr } \\
\text { Power } \\
\text { Kw/ft } \\
\end{array}$ & $\begin{array}{l}\text { Current } \\
\text { Burrup } \\
\text { at. } \% \\
\end{array}$ & Status \\
\hline Uง 3 & $\mathrm{MC}+5 \mathrm{v} / \mathrm{o} \mathrm{M}_{2} \mathrm{C}_{3}$ & 84 & $3165 S$ & 0.030 & 0.004 & $\mathrm{He}$ & 1750 & 18.0 & 11.1 & NDT - out \\
\hline U94 & $\mathrm{MC}+5 \vee / \circ \mathrm{M}_{2} \mathrm{C}_{3}$ & 84 & $316 \mathrm{SS}$ & 0.015 & 0.007 & $\mathrm{He}$ & 1680 & 21.9 & 10.7 & NDT - out \\
\hline v97 & $\mathrm{MC}+5 v / \mathrm{OM}_{2} \mathrm{C}_{3}$ & 84 & INC-800 & 0.030 & 0.004 & $\mathrm{He}$ & 1750 & 18.0 & 11.0 & NDT - out \\
\hline U98 & $M C+5 v / o M_{2} C_{3}$ & 84 & INC- 800 & 0.015 & 0.007 & $\mathrm{He}$ & 1680 & 21.9 & 10.6 & NDT - out ${ }^{c}$ \\
\hline U105 & $\mathrm{MC}+5 \vee / \mathrm{o}_{2} \mathrm{C}_{3}$ & 84 & INC -800 & 0.030 & 0.008 & $\mathrm{He}$ & 1900 & 15.1 & 11.5 & NDT - out \\
\hline ¿106 & $\mathrm{MC}+5 \vee / \mathrm{OM}_{2} \mathrm{C}_{3}$ & 84 & INC- 800 & 0.015 & 0.009 & $\mathrm{He}$ & 1825 & 19.8 & 10.9 & SDT - out $^{\mathrm{C}}$ \\
\hline U110 & $M C+10 v / 0 M_{2} C_{3}$ & $99^{b}$ & INC -800 & 0.015 & 0.014 & $\mathrm{He}$ & 1960 & 21.9 & 10.1 & NDT - out \\
\hline J113 & $\mathrm{MC}+10 \mathrm{v} / \mathrm{o} \mathrm{M}_{2} \mathrm{C}_{3}$ & $99^{b}$ & INC-800 & 0.030 & 0.010 & He & 1880 & 16.9 & 11.4 & NDT - o:tr \\
\hline U114 & $\mathrm{MC}+10 \vee / 0 \mathrm{M}_{2} \mathrm{C}_{3}$ & $99^{\mathrm{b}}$ & INC -800 & 0.015 & 0.007 & He & 1575 & 22.1 & 10.4 & NDT - out $^{c}$ \\
\hline
\end{tabular}

${ }^{\mathrm{a}} \mathrm{M}=\left(\mathrm{U}_{0.85}{ }^{\mathrm{P} \mathrm{u}_{0.15}}\right)$

${ }^{b}$ Cored pellet with nominal 0.080 - $\mathrm{tn}$. diameter axial hole.

${ }^{c}$ Fallure indicated by $\gamma$-Bcan at EBR-II.

investigated in this series, i.e., the introduction of internal porosity by the use of either low-density solid fuel pellets or high-density cored pellets. These experiments reached their goal burnup of 10 at.\% in subassembly X-142 after operation at moderate linear power ratings (approximately $20 \mathrm{Kw} / \mathrm{ft}$ ). Indications of element failure for three experiments were found at EBR-II using $\gamma-$ scanning for ${ }^{133} \mathrm{Xe}$. These capsules are in transit to the LASL hot cells.

The Series U1950 experiments are described in Table 463-IV. In these experiments, either two-phase or single-phase carbide fuel is helium bonded to Type 304 or 316 stainless steel or to Incoloy $800 \mathrm{cladding}$. Fuel densities range from 75 to $99 \%$ of theoretical. These experiments are currently at about three-fourths of their goal burnup after operation at low linear power (10 to $15 \mathrm{Kw} / \mathrm{ft}$ ). An interim examination is scheduled after EBR-II Run 58.

The Series U1930 and U1960 experiments are described in Tabie 463-V. Experimental parameters include fuel type, fuel density, bond type, and cladding type. The operating linear power ratings for the experiment are relatively high (30-35 $\mathrm{Kw} / \mathrm{ft})$. Nondestructive examination of the experiments listed in part $A$ of Table $463-V$ was completed several months ago. The results of these examinations showed that fuel elements U194 and U200 had failed. Destructive examination of U194 is currently under way. Significant results that have been determined for U194 are:

1. Only a very small amount, $<0.1 \mathrm{~cm}^{3}$ at STP, of fission gas was released from the element to the capsule plenum.

2. Approximately $2 \mathrm{~cm}^{3}$ of sodium were transferred from the element to the capsule.

3. No significant amount of fission gas was released from the fuel element during the de-encapsulation procedure, which included heating the experiment to melt the sodium in the capsule-element annulus.

4. A suspect area delineated by a stain on the cladding was observed about $8-5 / 8$ in. from the bottom weld.

5. Several regions of cladding ovality were observed in the fuel region of the element. In only one region, from 8 to $9-1 / 2$ in. from the bottom weld, were 
TABLE $463-T V$

SERIES U1950 CARBIDE EXPERIMEATS

\begin{tabular}{|c|c|c|c|c|c|c|c|c|c|c|}
\hline $\begin{array}{c}\text { Experiment } \\
\text { Bo. }\end{array}$ & Fuel Type ${ }^{a}$ & $\begin{array}{c}\text { Fuel } \\
\text { Density } \\
\text { G.T.D. }\end{array}$ & $\begin{array}{c}\text { Clad } \\
\text { Material }\end{array}$ & $\begin{array}{c}\text { Clad } \\
\text { Thickness, } \\
\text { in. } \\
\end{array}$ & $\begin{array}{l}\text { Diametral } \\
\text { Gap, in. }\end{array}$ & $\begin{array}{l}\text { Fuci- } \\
\text { To- } \\
\text { Clad } \\
\text { Bond }\end{array}$ & $\begin{array}{l}\text { Max. Fuel } \\
\text { Temp. at } \\
\text { Startup. }{ }^{\circ}\end{array}$ & $\begin{array}{l}\text { Max. } \\
\text { Linear } \\
\text { Power } \\
\underline{\text { Kw } / \mathrm{it}} \\
\end{array}$ & $\begin{array}{l}\text { Current } \\
\text { Burnup } \\
\text { at. \% }\end{array}$ & Status \\
\hline $\mathrm{U} 12 \mathrm{~g}$ & $\mathrm{MC}+5 \mathrm{v} / \mathrm{O} \mathrm{M}_{2} \mathrm{C}_{3}$ & 84 & $316 \mathrm{SS}$ & 0.022 & 0.016 & $\mathrm{He}$ & 1755 & 12.8 & 8.3 & $x \operatorname{cs} 5 A-\ln$ \\
\hline $\mathrm{C} 130$ & $M i C+5 \mathrm{v} / 0 M_{2} C_{3}$ & 75 & $316 \mathrm{SS}$ & 0.022 & 0.010 & $\mathrm{He}$ & 1500 & 13.1 & 8.3 & $\mathrm{X} 0.55 \mathrm{~A}-$ in \\
\hline L131 & $\mathrm{AC}+5 \mathrm{v} / 0 \mathrm{M}_{2} \mathrm{C}_{3}$ & 84 & $316 S S$ & 0.022 & 0.010 & $\mathrm{He}$ & 1495 & 13.1 & 8.2 & $x 055 A-$ in \\
\hline L132 & $\mathrm{MC}+5 \mathrm{v} / \mathrm{om}_{2} \mathrm{C}_{3}$ & 84 & $316 \mathrm{SS}$ & 0.022 & 0.010 & $\mathrm{He}$ & 1495 & 12.8 & 8.1 & $X U j 5 A-I \pi$ \\
\hline C133 & $\mathrm{MC}+5 \mathrm{v} / 0 \mathrm{MI}_{2} \mathrm{C}_{3}$ & 84 & $316 \mathrm{SS}$ & 0.022 & 0.010 & $\mathrm{He}$ & 1495 & 12.8 & 7.9 & $x 055 \Lambda-$ in \\
\hline $\mathrm{CH3}$ & $\mathrm{MC}+5 \mathrm{v} / 0 \mathrm{M}_{2}, \mathrm{C}_{3}$ & 84 & $316 \mathrm{SS}$ & 0,022 & 0.010 & $\mathrm{He}$ & 1495 & 12.8 & 7.9 & $x 055 \mathrm{~A}-$ in \\
\hline$[135$ & $\mathrm{MC}+5 \mathrm{~V} / \mathrm{O} \mathrm{M}_{2} \mathrm{C}_{3}$ & 84 & $\mathrm{LNC}-800$ & 0.022 & 0.010 & He & 1475 & 12.8 & 8.2 & XO55 A - in \\
\hline$[136$ & $\mathrm{MC}+5 \mathrm{v} / \mathrm{o} \mathrm{M}_{2} \mathrm{C}_{3}$ & 84 & NNC -800 & 0.022 & 0.010 & He & 1475 & 13.3 & 7.9 & $x 05 \overline{5} A-$ in \\
\hline :137 & $\mathrm{MC}+10 \mathrm{v} / \mathrm{O} \mathrm{MI}_{2} \mathrm{C}_{3}$ & 90 & $316 \mathrm{SS}$ & 0.022 & 0.010 & He & 1440 & 23.4 & 6.9 & XUjōA - in \\
\hline $\operatorname{Lis} 3 \mathrm{~A}^{b}$ & $\mathrm{MC}+10 \mathrm{v} / \mathrm{OM} \mathrm{M}_{2} \mathrm{C}_{3}$ & 90 & $3165 \mathrm{~S}$ & 0.022 & 0.010 & $\mathrm{He}$ & 1440 & 14.8 & 3.3 & XUラJA - in \\
\hline $\mathrm{L} 239$ & $\mathrm{MC}+10 v / 0 \mathrm{M}_{2} \mathrm{C}_{3}$ & 99 & LNC-80C & 0.022 & 0,010 & He & 1440 & 14.8 & 7. 0 & $x 05.3 \mathrm{~A}-$ in \\
\hline $\mathrm{U} 14 \mathrm{D}$ & $\mathrm{MC}$ & 93 & INC -800 & 0.022 & 0.010 & $\mathrm{He}$ & 1460 & 13.9 & 7.5 & $x 1555 \mathrm{~A}-1 \mathrm{n}$ \\
\hline $\mathrm{U} 141$ & MC & 93 & $316 \mathrm{SS}$ & 0.022 & 0.010 & $\mathrm{He}$ & 1460 & 14.3 & 7.4 & $x 055 A-$ in \\
\hline $1: 142$ & $\mathrm{MC}$ & 93 & $3165 S$ & 0.022 & 0.010 & $\mathrm{He}$ & 1460 & 14.5 & 7.5 & xoj5A - in \\
\hline U1*3 & $\mathrm{MC}+10 \mathrm{v} / 0 \mathrm{M}_{2} \mathrm{C}_{3}$ & $99^{c}$ & INC-800 & 0.022 & 0.010 & $\mathrm{He}$ & 1395 & 12.8 & 7.7 & XojoA - in \\
\hline $\mathrm{U}: 144$ & $M C+10 v / o M_{2} C_{3}$ & $99^{\mathrm{c}}$ & $316 \mathrm{SS}$ & 0.022 & 0.010 & $\mathrm{He}$ & 1395 & 13.1 & 7.8 & xoj̄at - in \\
\hline (143 & $\mathrm{MC}$ & 93 & $3045 \mathrm{~S}$ & 0.015 & 0.030 & $\mathrm{Na}$ & 820 & 13.4 & 7.3 & $\mathrm{X05} \overline{\mathrm{i}} \mathrm{A}-$ in \\
\hline $\operatorname{Lisiof} 0^{\circ}$ & $\mathrm{MC}+10 \mathrm{v} / 0 \mathrm{MI}_{2} \mathrm{C}_{3}$ & 39 & 304 SS & 0.015 & 0.036 & Na & $B 10$ & 13.7 & 3.3 & $\operatorname{xos} 5 \mathrm{~A}-$ in \\
\hline$\lcm{1+7}$ & $\mathrm{MC}+10 \vee / 0 \mathrm{M}_{2} \mathrm{C}_{3}$ & 99 & IN C -800 & 0.015 & 0.030 & $\mathrm{Na}$ & 810 & 14.2 & 7.4 & $\mathrm{X} 655 \mathrm{~A}-$ in \\
\hline
\end{tabular}

there peaks in the profilometry curves at $90^{\circ}$ with respect to each other.

6. An eddy current test of the cladding did not indicate a failure point. An apparent increase in bond electrical conductivity accurred about 6 in. above the bottom weld.

7. A test, comprised of heating the element to $\sim 150^{\circ} \mathrm{C}$ and pressurizing to $20 \mathrm{psig}$, resulted in neither loss of pressure nor evidence of sodium expulsion.

The results indicate: (1) a failure of the fuel element below the effective element sodium bond level that was present after the failure, and (2) a very small failure cross-sectional area and/or a failure area that is presently plugged. Metallographic examinat ion of the lower weld, which could not be adequately examined either visually or with the eddy current test, and of the suspect region at $8-5 j 8$ in. from the bottom weld are in progress in an effort to determine the point of fallure and the nature of the failure. Because the amount of sodium loss from the clement to the capsule indicates a partial unbonded condition during operation after the failure, metallographic examination of sections from the lower and upper regions of the fuel column will be made in order to determine if there was a significant difference in fuel operating temperature in these regions.

The experiments listed in part $B$ of Talle $463-V$ are currently being irradiated or are awaiting reinsertion into the reactor. The experiments listed in part $\mathrm{C}$ of Table $463-V$ were used as replacement pins in order to allow the irradiation to be continued to the desired burnup in the lead experiments. Only a cursory post-irradiaation examination is planned for these elements. The experiments listed in part $D$ of Table $463-V$ are awaiting insertion into the reactor. Capsule U261 will be returned 
TABLL : : :3-V

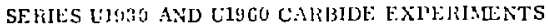

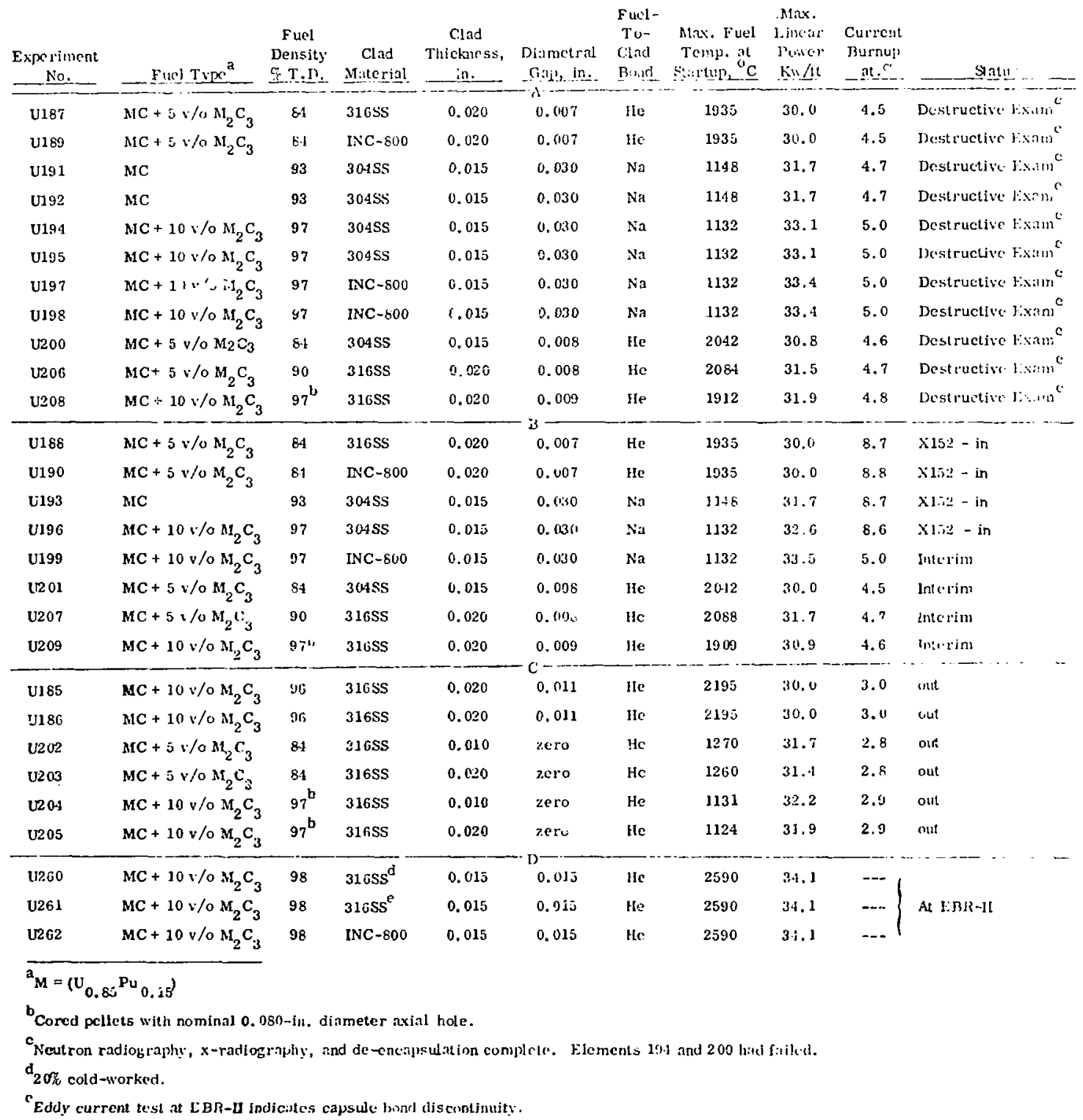

to LASL for rework of an apparent sodium bond defect in the capsule-element anrulus.

Table 463-VI describes the Series B-1 and B-2 experiments. These capsules are fueled with single-phase, uranium-plutonium mononitride. All the elements in this series are sodium-bonded and clad with either Type 304 or 316 welded stainless steel tubing. Operating linear power ratings for the experiments are relatively high (25$35 \mathrm{Kw} / \mathrm{ft}$ ). Capsules B-1-4 and B-2-5 have been examined using $\gamma-5$ canning techniques for the detection of ${ }^{137} \mathrm{Cs}$, and both elements are apparently intact. Destructive examination of capsule $\mathrm{B}-2-8$ gave no indication of element failure after 3.6 at. $\%$ burnup. The respits of the latter examination are reported in BMI-1925. ${ }^{2}$ Further irradiation of $B-1-4$ and $B-2-5$ is planned. The remaining experiments from this series are in subassembiv $\times 152$ which is scheduled for an interim examination at the end of EBR-II Run 58, B-1-1, B-2-1, and B-2-6 will have been irradiated to their goal burnup at the end of Run 58 . 
TABLẼ $463 \cdots V 1$

SERIES B-1 AND B-2 EBR-II NIT RIDE EXPERIMENTS ${ }^{a}$

\begin{tabular}{|c|c|c|c|c|c|c|}
\hline $\begin{array}{c}\text { Experiment } \\
\text { No. }\end{array}$ & $\begin{array}{c}\text { Fuel Density, } \\
\text { C.D. }\end{array}$ & $\begin{array}{c}\text { Smear Density, } \\
\text { CT.D. }\end{array}$ & $\begin{array}{l}\text { Clad ciing Wall } \\
\text { Thickness, in. }\end{array}$ & $\begin{array}{l}\text { Max. Linentr } \\
\text { Powes, Kw, ft }\end{array}$ & $\begin{array}{c}\text { Current Burnup } \\
\text { at. }\end{array}$ & Statilus \\
\hline$B-1-1$ & 94.1 & 80.2 & 0.020 & 27.9 & 6.5 & X15: - in \\
\hline B-1-2 & 93,9 & 80.5 & 0.020 & 27.1 & fi.̈3 & $x 15-$ in \\
\hline B-1-4 & 93.8 & 84.9 & 0.020 & 28.6 & 3.0 & $\begin{array}{l}\text { Nondest ructive } \\
\text { Exant }\end{array}$ \\
\hline$B-2-1$ & 94.7 & 81.5 & 0.020 & 32.7 & 6.3 & $\times 152-$ in \\
\hline$B-2-2$ & 94.4 & 81.5 & 0.020 & 32.0 & li.2 & $x 152-$ in \\
\hline$B-2-3$ & 94.0 & 81.0 & $? .020$ & 32.4 & 6.3 & $\mathrm{X} 152-$ in \\
\hline$B-2-5$ & 94.2 & 75.5 & (i. 025 & 32.4 & 3.0 & $\begin{array}{l}\text { Nondestructive } \\
\text { Exam }\end{array}$ \\
\hline$B-2-6$ & 94.0 & 81.8 & 0.010 & 36.6 & 6.2 & $\mathrm{X} 152-$ in \\
\hline$B-2-7$ & 93.9 & 81.7 & 0.010 & 56.7 & 6.1 & $\mathrm{X} 152-$ in \\
\hline$B-2-8$ & 93.8 & 81.6 & $0 .(10$ & 36.5 & 3.6 & Complete \\
\hline
\end{tabular}

${ }^{\text {a }}$ All capsules are sodium bonded. Capsule cladding is $0.375 \mathrm{in.} 0 . \mathrm{d}$. $\mathrm{x} 0.33 \mathrm{j}$ in. i.d. Type 304 stainless steel. Element cladding for the B-1 experiments is welded $0.290 \mathrm{in.}$ o.d. Type 304 stainless steel.

Element cladding for the Series B-2 experiments is welded $0.315 \mathrm{in}$. $0 . \mathrm{d}$. Type 316 stainless stecl.

The fuel is $\left(\mathrm{U}_{0.8} \mathrm{Pu}_{0,2}\right)^{\mathrm{N}}$.

The B-3 series of experiments are described in

Table 463-vII. This nitride-fueled series is similar to the B-1 and B-2 series except that three helium bonded experiments are included and the average operating linear power ratings are slightly higher. Gamma-scans made at EBR-II for ${ }^{133}$ Xe indicated that the four sodiumbonded elements have failed, while the three heliumbonded elements have not failed. Preliminary visual examination at LASL indicates that the four failed elements are bowed as much as $3 / 8 \mathrm{in}$. Nondestructive examination of the failed elements is currently under way.

The Series U5100 singly-clad experiments are described in Table 463-VIII. In this group, either singlephase or two-phase carbide fuel is sodium bunded to Type 304 or 316 stainless steel or to Incoloy 800 . In seven of the elements, a shroud is incorporated primarily $t \cdot$ test the retention of fuel fragments by close fitting tubes. A secondary objective of the shroud is to study the eff.sctiveness of the shroud alloy as a carbon getter. Experiment U255 has been rejected due to a tungsten inclusion in the bottom weld. That experiment will be replaced with a stainless steel dummy element. Insertion of the experiments into the reactor is pending completion of the quality assurance data package by the Gulf United Nuclear Fuels Corporation, the original experimenter.

The $\mathrm{C}-5$ series of singly-clad experiments is described in Table 463-IX. Single-phase nitride fuel is sodium bonded to $20 \%$ cold-worked Type 316 stainless steel cladding in all of the fuel elements in this group. Profilometry measurements of the $\mathrm{C}-5$ series elements have been made using the same equipment that will be used $\mathrm{fo}_{\star}$ the postirradiation examination. The LASL nondestructive fiseile assay results indicate that the ${ }^{239} \mathrm{Pu}$ content of the pins is $3 \%$ lower than the values based on the nominal composition. This diserepancy may be resolved when the quality assurance documents are received from BMI, the original experimenter. Shipment of selected elements to EBR-II is pending receipt of these documents and a LASL review of the experiments from a quality assurance standpoint.

The $O-N 1$ series of singly-clad experiments is described in 'Tahle 463-X. These experiments are similar to the $C-5$ series. The elements are fueled with $\left(\mathrm{U}_{0.8} \mathrm{Pu}_{0.2}\right) \mathrm{N}$ which is sodium bonded to $20 \%$ cold-worked Type 316 stainless steel cladding. These elements were received with the cladding in the fueled region in an 
TABLE $463-V] 1$

SERIES B-3 EBR-II NITRIDE EXPERIMENTS ${ }^{a}$

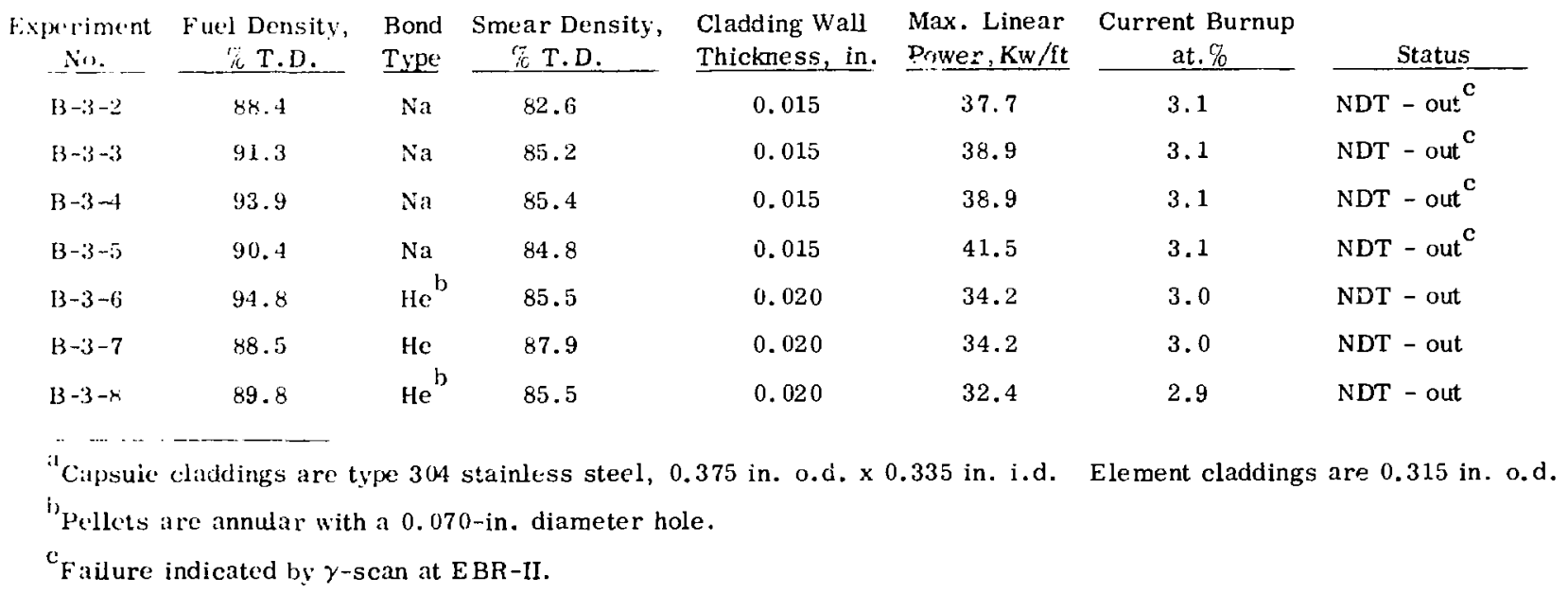

oxidized condition. All clements were eiectropolished to remove the cladding oxidatinn. The average and maximum diameter decreascs after electropolishing were 0.0003 and 0.0005 in., respectıvely. Three elements have been rejected because of large fuel chips in the sodium annulus. The diameters of the elcments have been measured on the same profilometer that will be used after irradiation. Nondestructive fissile assay results agree well with those calculated from the nominal composition. The status or shipment of these experiments to EBR-II is the same as for the $\mathrm{C}-5$ series. Four of the fuel pins from Series $\mathrm{O}-\mathrm{N} 1$ will be irradiated with fifteen pins from Series $\mathrm{C}-5$.

The tentative description of the $\mathrm{K} 4$ series of experiments is shown in Table 463-X1. One of the primary purposes of the $\mathrm{K} 4$ Series is to provide data for a critical comparison of the overall irradiation behavior of carbide and nitride fuel elements which have been irradiated under conditions that are, as nearly as possible, identical. The test parameters include fuel type, cladding colr-work, smear density, linear power rate, operating temperature, fuel restraint, and burnup. The fuel used in the fabrication of these elements will be $95 \%$ dense, single-phase $\left(\mathrm{L}_{0.8} \mathrm{Pu}_{0.2}\right) \mathrm{C}$ or $\left(\mathrm{U}_{0.8} \mathrm{Pu}_{0.2}\right) \mathrm{N}$. The carbide fuel will be fabricited at LASL from material synthesized using the are-melting process. Material prepared by the carbothe rmic reduction process may also be used. The nitride fuel for the initial loadings will be supplied by Battelle Mernorial Institute and will be prepared using the hydridenitride process. BMI has produced 15 batches of fuel of which 4 batches have been received. The cladding tubing will be Type 316 stainless sieel $0.310 \mathrm{in}$. o.d. With a wall thickness of $0.012 \mathrm{in}$. The lladding was purchased through HEDL from Superior Tube Co. Both solution annealed and $20 \%$ cold worked tubing were purchased. The tubing complies, as nearly as possible, to the fuel element cladding specification RDT-E13-8. End plug material has been received from HEDL. The $20 \%$ cold-worked, Type 316 stainless steel for the end plugs is a portion of the batch of bar stock fabricated for the FFTF control rod structural components and complies tn RDT-M-7-23T. Hold-down springs will be made from 0.031-in.-diam, Type 302 stainless steel, FFTF driver fuel element spacer wire material.

Shroud tubes with perforated slots are planned for use as a fuel fragment lestraint mechanism in about 10 of the Series $\mathrm{K}-4$ fuel elements. The actual number of elements that will use shrouds will depend on the analysis of the results for the sodium-bonded elements from the encapsulated experiments currently being examined. The suggested shroud tube geometry was selected after considering several wire restraint systems, tubular restraint systems, and packing restraint systems. The suggested shroud tube is: 


\begin{tabular}{|c|c|c|c|c|c|c|c|c|}
\hline $\begin{array}{c}\text { Exprerinent } \\
\text { No. }\end{array}$ & Fuct Tuge & $\begin{array}{c}\text { Finl } \\
\text { Density, } \\
\text { T.D. }\end{array}$ & $\begin{array}{c}\text { Ciud } \\
\text { Material } \\
\end{array}$ & Shroud & $\begin{array}{l}\text { Dinneriol } \\
\text { Gipe, in. } \\
\end{array}$ & 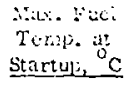 & $\begin{array}{l}\text { Max, Lincan } \\
\text { Power, KW/ft }\end{array}$ & ___ StaLtus \\
\hline$[=2 \div 1$ & $\operatorname{MIC}$ & 4is & 30 iss & Sore & 0.015 & $113 \overrightarrow{0}$ & 35.8 & 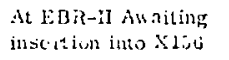 \\
\hline$l \div 2+2$ & $\mathrm{MC}$ & $\$ 3$ & $3 H S S$ & Sune & 0.013 & $11: 5$ & $3 \overline{5} .5$ & 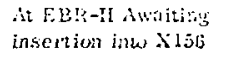 \\
\hline U243 & MC & 93 & $3045 S$ & None & 0.030 & 1150 & 33.8 & $\begin{array}{l}\text { At EBr-n Aw ailing } \\
\text { insertin thts } \times 156\end{array}$ \\
\hline $\mathrm{L} 25+4$ & $\mathrm{MC}$ & 93 & $30 \leq \mathrm{ss}$ & Sone & 0.025 & $117 \overline{\mathrm{j}}$ & 35.8 & 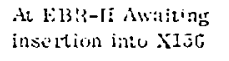 \\
\hline $\mathrm{U} 245$ & $\mathrm{MC}$ & 93 & $3045 S$ & None & 0.030 & 1150 & 33.8 & $\begin{array}{l}\text { At FBR-II Awaiting } \\
\text { insertion into } X 156\end{array}$ \\
\hline $\mathrm{U} 246$ & $\mathrm{MC}$ & 93 & $316 \mathrm{SS}$ & None & 0.010 & 1190 & 36.4 & $\begin{array}{l}\text { At EBR-1l Awhiting } \\
\text { inoc:ti,al into } x \perp 56\end{array}$ \\
\hline L29 47 & $\mathrm{MC}$ & 93 & $31 \cdots 3$ & None & 0.630 & 1150 & $3: 8$ & 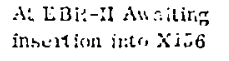 \\
\hline $\mathrm{U} 248$ & $\mathrm{MC}$ & 93 & $316 \mathrm{SS}$ & None & 0.030 & 1110 & 36.4 & $\begin{array}{l}\text { At EBR-II Awajting, } \\
\text { unsention int: } \times 156\end{array}$ \\
\hline $2=49$ & $\mathrm{MC}$ & 93 & $5 \times C-500$ & Nore & 0.015 & 1210 & 36.4 & 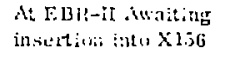 \\
\hline L250 & $\mathrm{MC}$ & 93 & NC- 800 & None & 0.030 & 1145 & 36.4 & 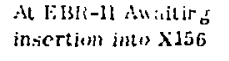 \\
\hline U25 1 & $\mathrm{MC}$ & 93 & $304 \mathrm{SS}$ & None & 0.030 & 1145 & 36.4 & $\begin{array}{l}\text { At EBh-ll fwaiting } \\
\text { iasstint into } \times 156\end{array}$ \\
\hline บ252 & $\mathrm{MC}$ & 93 & $3045 S$ & Vanadium-slots & 0.030 & $11 ; 0$ & 30.4 & 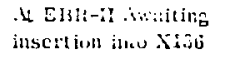 \\
\hline L253 & MC & 93 & $304 \mathrm{SS}$ & Iron-slots & 0.030 & $11-15$ & 33.8 & $\begin{array}{l}\text { he EBR-II hwaiting } \\
\text { insertin int, X1,j6 }\end{array}$ \\
\hline U254 & $\mathrm{NC}$ & 93 & $30: \mathrm{SS}$ & $30455-210 t s$ & 0.630 & $12 ; 0$ & 33.8 & 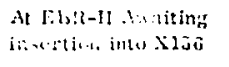 \\
\hline L255 & $\mathrm{MIC}$ & 93 & $304 \mathrm{SS}$ & 3otss-hoies & 0.130 & $-\infty$ & -- & 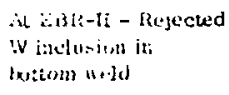 \\
\hline 2256 & $\mathrm{MC}+10 \mathrm{v} / \mathrm{e} \mathrm{M}_{2} \mathrm{C}_{3}$ & 98 & $3045 S$ & Vanadium-slots & 0.430 & 1140 & 3.1 .0 & $\begin{array}{l}\text { At } F(3) \text {-II Awdiling } \\
\text { inset:an int. } \times 150\end{array}$ \\
\hline L257 & $\mathrm{MC}+10 \mathrm{v} / \mathrm{O} \mathrm{M}_{2} \mathrm{C}$ & 98 & INC-800 & Tantalum-sl ots & 0.030 & 1135 & 33.5 & $\begin{array}{l}\text { At EBL-II Awatirg } \\
\text { inseltion inia XIJo }\end{array}$ \\
\hline U258 & $\mathrm{MC}+10 \mathrm{v} / 0 \mathrm{Mr}_{2} \mathrm{C}_{3}$ & 98 & $3045 S$ & 304SS-sl ots & 0.030 & 1145 & 33.5 & $\begin{array}{l}\text { As k.1BR-tr Awafting } \\
\text { inseltion into X136 }\end{array}$ \\
\hline U259 & $\mathrm{MC}+10 \times / 0 \mathrm{M}_{2} \mathrm{C}_{3}$ & 98 & $\mathrm{INC}-800$ & 302SS-stots & 0.030 & 1150 & 34.6 & $\begin{array}{l}\text { At EBR-II Awaiting } \\
\text { insertion into } \times 156\end{array}$ \\
\hline
\end{tabular}

1. perforated with slots,

12. method of slot fabrication, Electro Discharge Machine (EDM).

2. slot axial pitch, 0.125 in.,

3. slot length, 0.100 in.,

In addition to the experiments described aboye, $t w o$

4. slot width, 0.020 in.,

5. twenty-four slots per tube revolution,

6. adjacent circumferential rows of slots staggered axially by $1 / 3$ the axial pitch,

7. circumferential ligament between slots, 0.015 in.

8. axial ligament between slots, 0.025 in.,

9. tube dimensions, 0.2675 in. $\times 0.2615$ in.,

10. Slot area, 43.8\%,

11. tube material, $25 \%$ cold-worked Type 316 stainless steel, nitride fueled thermal irradiation experiments from ORNI (43N1 and 43N2) and eight carbide fueled EBR-II experiments from Westinghouse will be examined. Results and status $w$ ill be reported in future reports pending receipt of experiment desciption and history.

Several pieces of equipment for the fuel element loading facility are undergoing testing and modifications. The design and assembly of the xerion tagging apparatus has been completed and is ready for testing. The eddy current testing apparatus has been operated successfully 
TAELF: $\div 5 j-Z X$

SERIES C-5 EBR-II NiTTRDE EXPERIMINTS ${ }^{2}$

\begin{tabular}{|c|c|c|c|c|c|c|}
\hline $\begin{array}{c}\text { Experiment } \\
x \text { sio. } \\
\end{array}$ & $\begin{array}{r}\text { Fuel Density, } \\
\text { T.D. } \\
\end{array}$ & $\begin{array}{c}\text { Smear Density, } \\
r \text { r.J. }\end{array}$ & $\begin{array}{c}\text { Max. Fuel } \\
\text { Temp at } \\
\text { Startup, }{ }^{\circ}\left({ }^{\circ} \mathrm{C}\right)\end{array}$ & $\begin{array}{c}\text { Max. Clad } \\
\text { Temp. }=\left(^{\circ} \mathrm{C}\right)\end{array}$ & $\begin{array}{l}\text { Max. Linear } \\
\text { Power, Kw/ft }\end{array}$ & Stintus \\
\hline$C-5-1$ & 92.6 & 79.4 & - & - & -- & Reject; chips, air in plenum \\
\hline$C-5-2$ & 93.3 & 79.4 & - & - & $\cdots$ & Reject; chips, air in plent $m$ \\
\hline$C-5-3$ & 94.0 & 79.9 & -- & -- & -- & Reject; chips, air in plenum \\
\hline$C-5-4$ & 95.1 & 80.9 & $2112(1150)$ & $1320(719)$ & 33.2 & At LASL for NDT \\
\hline$C-5-5$ & 95.4 & 81.6 & $-\infty \times-\infty----$ & --SPARE------ & $---\cdots-$ & At LASL for NDT \\
\hline$c-5-6$ & 93.3 & 79.3 & $2116(1158)$ & $1328(720)$ & 33.3 & At LASL for NDT \\
\hline$C-j-7$ & 94.4 & 80.5 & $2164(11 S 4)$ & $1336(724)$ & 33.7 & At LASL for NiDT \\
\hline$C-5-8$ & 94.3 & 74.4 & $2001(1127)$ & $1154(623)$ & 32.7 & At IASL for NDT \\
\hline$C-5-9$ & 94.2 & 80.2 & $2071(1133)$ & $1203(651)$ & 33.5 & At LASL for NDT \\
\hline$C-5-10$ & 94.1 & 80.2 & $2021\langle 1105\rangle$ & $1157 !(25)$ & 32.6 & At LASL for NDT \\
\hline$C-\overline{3}-11$ & 93.9 & 80.6 & $2050(1121)$ & $1165(029)$ & 33.4 & At LASL for NDT \\
\hline$C-5-12$ & 94.2 & 74.1 & $2050(1121)$ & $1191(64-4)$ & $3: 2.5$ & Al LASL IO: NDT \\
\hline$C-5-13$ & 95.5 & 75.2 & $2036(1113)$ & $1154(623)$ & 32.1 & At L.ASL for NDT \\
\hline$C-5-14$ & 95.7 & 75.4 & $2087(1142)$ & $1312(711)$ & 32.0 & At IASL for NDT \\
\hline$C-5-15$ & 95.2 & 75.4 & $2036(1113)$ & $1188(6.12)$ & 32.1 & AL LASL fOY ND'T \\
\hline$c-5-1 c$ & 95.6 & 75.4 & $\ldots$ & $--\operatorname{SPARE}-\cdots$ & ------ & At LASL ïor NDT \\
\hline$C-5-17$ & 95.7 & 75.5 & -- & -- & -- & Rcject; leaked, air in plenum \\
\hline$C-5-18$ & 93.9 & 79.6 & $2039(1115)$ & $1193(645)$ & 32.6 & At LASL for NET \\
\hline$C-5-19$ & $93 . \hat{~}$ & 78.9 & $2054(1123)$ & $1200(G+9)$ & 33.0 & At LASL for NDT \\
\hline$C-5-20$ & 94.7 & 80.6 & $2024(1167)$ & $1155(\varepsilon 24)$ & 32.4 & At LASL for XDT \\
\hline
\end{tabular}

a All elements are sodium bonded. The fuel is $\left(\mathrm{U}_{0.8^{\mathrm{Pu}}} \mathrm{u}_{0.2}\right) \mathrm{N}$ pellets.

The cladding is $20 \%$ cold-worked Type 316 stainless steel, $0.310 \mathrm{in}$. $0 . d$. by $0.280 \mathrm{in}$. i.d.

TABLE 463-X

SERIES O-N1 EBR-II NITRIDE EXPERIMENTS ${ }^{a}$

\begin{tabular}{|c|c|c|c|c|c|c|}
\hline $\begin{array}{c}\text { Experiment } \\
\text { No. }\end{array}$ & $\begin{array}{c}\text { Fuel Density, } \\
\text { T.D. }\end{array}$ & $\begin{array}{c}\text { Smear Density } \\
\% \mathrm{~T}, \mathrm{D}\end{array}$ & $\begin{array}{l}\text { Temp, at } \\
\text { Startup, }{ }^{\text {F }}\left({ }^{\circ} \mathrm{C}\right)\end{array}$ & 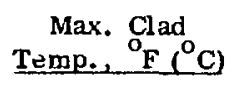 & $\begin{array}{r}\text { Max. Linear } \\
\text { Power, Kw/ft } \\
\end{array}$ & Status \\
\hline$O-N 1-1$ & 89.9 & 77.7 & $2085(1140)$ & $1200(649)$ & 32.9 & At LASL for NDT \\
\hline $\mathrm{O}-\mathrm{N} 1-2$ & 90.3 & 78.0 & 2043 (1117) & $1325(718)$ & 33.1 & At LASL for NDT \\
\hline $\mathrm{O}-\mathrm{N} 1-3$ & 90.0 & 77.8 & $2128(1164)$ & $1323(717)$ & 32.6 & At LASL for NDT \\
\hline $\mathrm{O}-\mathrm{N} 1-4$ & 89.6 & 77.4 & $2133(1167)$ & $1323(717)$ & 32.8 & At LASL for NDT \\
\hline $\mathrm{O}-\mathrm{N} 1-5$ & 90.4 & 78.1 & $2068(1131)$ & $1160(627)$ & 32.9 & At LASL for $\mathrm{NDT}^{b}$ \\
\hline$O-N 1-6$ & 89.3 & 77.2 & -............ & -SPARE - - & $-\cdots-\infty$ & At LASL for NDT ${ }^{b}$ \\
\hline $0-\mathrm{N} 1-8$ & 89.6 & 77.4 & - & -SPARE- - & $-\cdots--$ & At LASL for NDT \\
\hline
\end{tabular}

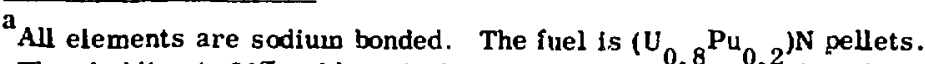

The cladding is 20 cold-worked. Type 316 stainless 3 teel, $0.310 \mathrm{in}$. o.d. by 0.280 in. i.d.

blements $0-\mathrm{N} 1-2,-5$, and -6 have large fuel chips in the pellet-cladding annulus.
} 
TABLE 463-XI

SERIES K+ CARBDE EXPERIMENTS ${ }^{\mathrm{a}}$

\begin{tabular}{|c|c|c|c|c|c|c|c|}
\hline $\begin{array}{c}\text { Experiment } \\
\text { זio. } \\
\end{array}$ & $\begin{array}{l}\text { Fuel } \\
\text { Trupe }\end{array}$ & $\begin{array}{c}\text { Smear } \\
\text { Density, is }\end{array}$ & Cladding $^{c}$ & Shroud & $\begin{array}{l}\text { Peak Cladding } \\
\text { Temp. }{ }^{\circ} \mathrm{F}(\mathrm{C})\end{array}$ & $\begin{array}{c}\text { Centerline Temp., } \\
{ }^{\circ}{ }^{\circ}\left({ }^{\circ} \mathrm{C}\right) \\
\end{array}$ & $\begin{array}{c}\text { Goal Burnup. } \\
\text { at. }{ }^{\prime}:\end{array}$ \\
\hline 52 & $\mathrm{C}$ & 82 & $\mathrm{SA}$ & Yes & $1060(570)$ & $1900(1040)$ & 7 \\
\hline 53 & $\mathrm{C}$ & 82 & SA & Yes & $1170(630)$ & $2000(1100)$ & 11 \\
\hline 54 & C & 82 & $S A$ & No & $1170(630)$ & $2000(1100)$ & 11 \\
\hline $5 \overline{5}$ & $C$ & 82 & $S A$ & No & $1060(570)$ & $1900(1040)$ & 7 \\
\hline 56 & $\mathrm{C}$ & 82 & $\mathrm{SA}$ & Yes & $1160(62 \overline{5})$ & $2000(1100)$ & 11 \\
\hline 57 & $\mathrm{C}$ & 82 & $\mathrm{CW}$ & Yes & $1050(565)$ & $1900(1040)$ & 11 \\
\hline 58 & $\mathrm{C}$ & 82 & $\mathrm{CW}$ & Yes & $1160(625)$ & $2000(1100)$ & 11 \\
\hline 59 & $\mathrm{C}$ & 82 & $\mathrm{CW}$ & No & $1050(565)$ & $1900(1040)$ & 11 \\
\hline 60 & $\mathrm{C}$ & 85 & $S A$ & No & $1050(565)$ & $1900(1040)$ & 7 \\
\hline 61 & $\mathrm{C}$ & 85 & $\mathrm{CW}$ & No & $1060(570)$ & $1900(1040)$ & 11 \\
\hline 62 & $\mathrm{~N}$ & 82 & $\mathrm{SA}$ & No & $1050(565)$ & $2400(1315)$ & 7 \\
\hline 63 & $\mathbf{N}$ & 82 & CW & No & $1170(630)$ & $2500(1375)$ & 11 \\
\hline 64 & $\mathbf{N}$ & 82 & $\mathrm{SA}$ & Yes & $1170(630)$ & $2500(1375)$ & 11 \\
\hline 65 & $\mathrm{~N}$ & 82 & $\mathrm{CW}$ & Yes & $1180(640)$ & $2500(1375)$ & 7 \\
\hline 66 & $\mathbf{N}$ & 82 & $\mathrm{CW}$ & Yes & $1070(575)$ & $2400(1315)$ & 11 \\
\hline 67 & $\mathrm{~N}$ & 82 & $S A$ & Yes & $1080(580)$ & $2400(1315)$ & 11 \\
\hline 68 & $\mathrm{~N}$ & 82 & $S A$ & Yes & $1050 ; 565)$ & $2400(1315)$ & 11 \\
\hline 69 & $\mathrm{~N}$ & 85 & SA & No & $1070(570)$ & $2400(1315)$ & 11 \\
\hline 70 & $\mathrm{~N}$ & 85 & $\mathrm{CW}$ & No & $1050(565)$ & $2400(1315)$ & 7 \\
\hline
\end{tabular}

${ }^{a_{H}}$ Heating rates will be in the range 38 to $40 \mathrm{Kw} / \mathrm{ft}$. All elements sodium bonded.

${ }^{\mathrm{b}} \mathrm{C}=95 \%$ dense $\left(\mathrm{U}_{0.8} \mathrm{Pu}_{0.2}\right) \mathrm{C}, 93 \%$ enriched ${ }^{235} \mathrm{U}$.

$\mathrm{N}=9.5 \%$ dense $\left(\mathrm{U}_{0.8} \mathrm{Pu}_{0.2}\right) \mathrm{N}, 93 \%$ enriched ${ }^{235} \mathrm{U}$.

$\mathrm{c}_{\mathrm{SA}}=$ solution annealed Type 316 stainless steel. $\mathrm{CW}=20 \%$ cold worked $\mathrm{T} y$ pe 316 stainless steel.

Both types are 0.310 in. o.d. by 0.266 in. i.d.

with the eddy current standard and a standard operating test procedure is being prepared.

\section{TREAT Irradiation Testing}

(J. F. Kerrisk, D. G. Clifton, R. E. Alcouffe)

In order to assess the behavior of (U, Pu)C and

(U, Pu)N fueled elements under fast reactor accident conditions, transient frradiations will be conducted in the IREAT facility. Investigations will be carried out on both irradiated and unirradiated fuel pins to determine (1) the threshold power levels at which damage or failure occurs, (2) the effect of bond and cladding defects, and (3) the failure propagation mechanism in multipin assemblies.
1. Series UL Tests. A cooperative effort has been carried out with Gulf United Nuclear. Fuels Corporation in the area of TREAT testing. A series of four tests, designated LASL Series UL, will determine the effect irradiation on the behavior of helium and sodium bonded advanced fuel elements (fabricated by GUNFC) under possible LMFBR accident conditions. Table 463-XII describes the fuel elements and test objectives. LASL has assumed complete responsibil ity for these tests in fiscal year 1973.

a. Tests LASL-UL-1 and LASL-UL-2. During this quartcr the capsules for these tests were received 
TAB1.E $163-\times$ II

LASL SERTES L'L TESTS

\begin{tabular}{|c|c|c|c|c|}
\hline & \multicolumn{4}{|c|}{ TEST } \\
\hline & $\overline{L A S L}-\mathrm{LL}-1$ & L.ISL-CL $=?$ & LASL- $-\overline{L-3}$ & $L A S L-L L=L$ \\
\hline Fucl filemen ${ }^{a}$ & $-363(138 A)$ & $264(1.46 \lambda)$ & $265(138)$ & $266(146)$ \\
\hline Fuel Mlaterial & \multicolumn{4}{|c|}{$90 \operatorname{vol} \mathrm{C}_{6}\left(\mathrm{~L}_{0.85} \mathrm{Pu}_{0.15}\right) \mathrm{C}+10 \mathrm{vol} \mathrm{C}_{\mathrm{C}}\left(\mathrm{L}_{0.85} \mathrm{Pu}_{0.15}\right)_{2} \mathrm{C}_{3}$} \\
\hline $\begin{array}{l}\text { Fuel Pollet } \\
\text { o.d., in. }\end{array}$ & 0.246 & 0.240 & 0.246 & 0.240 \\
\hline Bond Material & He & $\mathrm{Na}$ & He & Na \\
\hline $\begin{array}{l}\text { Bond Thickenss } \\
\text { (Padial), in. }\end{array}$ & 0.005 & 0.015 & 0.005 & 0.015 \\
\hline Clad Matcrial & $316 \mathrm{SS}$ & 30.15s & $3165 S$ & $304 S S$ \\
\hline $\begin{array}{l}\text { Clad Thickness, } \\
\text { in. }\end{array}$ & 0.022 & 0.015 & 0.022 & 0.015 \\
\hline $\begin{array}{l}\text { Smear Density, } \\
\text { f Theoretical }\end{array}$ & 90 & 77 & 90 & 77 \\
\hline $\begin{array}{l}\text { Fuel Culumo } \\
\text { Length, in. }\end{array}$ & \multicolumn{4}{|c|}{$13.75 \pm 0.125 \quad \ldots$} \\
\hline $\begin{array}{l}\text { Burnup, } \\
\text { MND/MT MC }\end{array}$ & 0 & 0 & 45,000 & 45,000 \\
\hline Test Objective & $\begin{array}{l}\text { Fuel } \\
\text { Alelting }\end{array}$ & $\begin{array}{l}\text { Fuel } \\
\text { Molting }\end{array}$ & $\begin{array}{l}\text { Sime Triun- } \\
\text { sient as } 263\end{array}$ & $\begin{array}{l}\text { Saroe Tran- } \\
\text { slent as } 264\end{array}$ \\
\hline
\end{tabular}

${ }^{\mathrm{a}}$ Fucl clement numbers reassigned by GUNFC. Old numbers shown in parentheses.

branlum enriched to $v^{\prime}$ : in ${ }^{235} \mathrm{U}$.

Ir radiatud in F.BR-II at 10 to $15 \mathrm{kw} / \mathrm{ft}$ in subas senbly X-055.

from GUNFC, the two leaking TREAT capsule heads were replaced with new heads, and the capsules were inspected and prepared for shipment to TREAT. The following sequence of operations was performed in achieving these results:

1. The TREAT capsules received from GUNFC were disassembled.

2. The inner capsules were $x$-radiographed and thermocouple circuits were tested for electrical continuity.

3. Three TREAT capsule heads with new potted epoxy electrical seals svere prepared, helium leak tested, hydrostatically tested to 15,000 psf, and helium leak tested again. A leak was found in the potted electrical seal of one of the heads after the hydrostatic test.

4. The two TREAT capsules were hydrostatically tested to 15,000 psi with no indication of leaks or damage.

5. The inner capsules and TREAT capsules were assembled using the leak tight heads and subjected to a helium leak test, an electrical continuity test, a visual examination, and a trial heat-up to pre-test lemperatures using the capsule heaters.

6. Both TREAT capsules we re $x$-radiographed in the assembled state as the last inspection prior to shipment, and loaded into the ir shipping container.

A quality assurance plan for tests LASL-UL- 1 and 1,ASL-UL-2 was written and accepted by the TREAT staff. This plan covers the inspections and tests performed at LASL and at TREAT prior to test in the TREAT Reactor as well as the post-test examination. Quality assurance procedures covering these inspections were also written. With the approval of this QA plan, LASL received permission to ship the capsules for these tests to TREAT.

b. Tests LASL-UL-3 ard LASL-UL-4. Tho assembly of the inner capsules for tests 3 and 4 of the UL Series was done by GUNFC up to the point of insertion if the fuel elements into the inner capsules. Since the fuel elements were pre-irradiated in EBR-II, the completion of the assembly of the iiner capsules and the assembiy of the inner capsules into the TREAT capsules requires hot cell facilities. LASL, in conjunction with RDT, has arranged for the completion of the assemly by the Radiometallurgy Group of Hanford Engineering Development Laboratory. LASL has recelved copies of HEDL procedures covering similar assembly operations for their TREAT experiments, reviewed the $m$, and is discussing possible changes with HEDL. The fuel elements and partially assembled inner capsules for these tests have been shipped to HEDL. A QA plan covering the completion of the assembly and inspections at HEDL and the post-test examination is in preperation.

\section{c. Neutronic Calculations. Calculations for} the UL Series experiments had bcen previously performed ${ }^{j, 4,5}$ using a preliminary cross-section set consisting of 24 epithermal and 5 thermal groups. However, this set underestimates the worth of some other experiments by 0.5 to $1.0 \mathrm{jk} / \mathrm{k}$. Therefore, this quarter has been devoted to obtaining and testing a new cross-section set. Because of the extreme changes in spectrum through the experimental materials it was felt that 5 thermal groups were insufficient; therefore, 20 thermal groups are used in the new set. Also, the $\mathrm{MC}^{2}$ code was used to 
obtain the cepithe rmal cross scctions from ENDF/B leading to a more accurate determination of the resonance self shielding effects. Thus the new set consists of 44 roups, 29 rpithermal and 20 thermal.

A sedites of both one-dimensional and two-dimensional calculations were performed for the UL series of $c x-$ periments to determine the changes prediuted by the new sei of cross sections. The results are presented in Table 463-XII. Because the calculated renctivity worth of the experiment is closer to the expected $3 i \mathrm{k} / \mathrm{k}$, it appears that the use of the new set does lead to significantly improved calculations of the system.

\section{Series 1 Tests. A group of eight tests using} LASL fabricated fuel elements has been designated LASL Series 1 tests. The tests ar a designed to determine if any significant safety related behavioral problems exist for sodium bonded, stainles', steel cladi $(\mathrm{U}, \mathrm{Pu}) \mathrm{C}$ and $(\mathrm{U}, \mathrm{Pu}) \mathrm{N}$ fuels by defining 'ajlure thresholds and the types of failure experienced $\cdots$ these fuels. Table $463-\mathrm{XIV}$ summarizes the test paraneters and objectives. Approval-in-principle has been received from the $\mathrm{AEC}$ for this series of tests. Design work for the modifieation of TREAT capsules to incorporate a thermal neutron filter and cal-dations for a prelir'inary safety anilysis tre in progress.

\section{Neutronic calculations have also been performed} for the Series 1 experiments using the new cross-section set, and based on a 0.010-in. -thick gadolinium the rmal neutron filter and a preliminary capsule design. Table 463 -XIII shows the results obtained.

\footnotetext{
TABLF + GO $-X W$

RESLLTS OF NELT HONCC C.UCLLATHONS

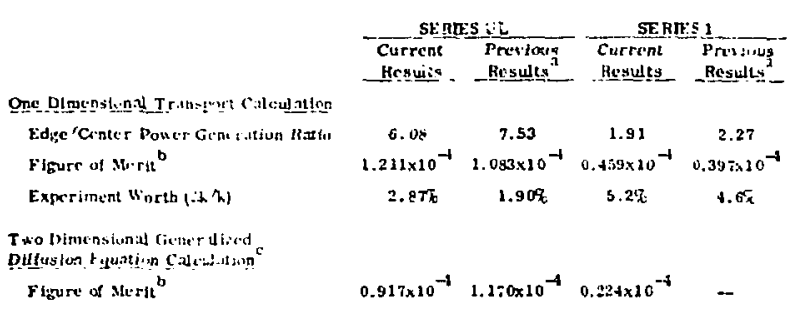

3 sec Heferences $3-5$.

byigure of merit iv the satio of the power density in the fuel to the power produeed by

the reactor in W/es: $\mathrm{w}$.

sec kuterence \&.
}

TABLF: $463-X I V$

\section{LAEL SERIES \& FXUEITMESTS}

\begin{tabular}{|c|c|c|c|c|}
\hline Test & $\begin{array}{c}\text { Fuel } \\
\text { Mitcriala }\end{array}$ & Burnus & $\begin{array}{l}\text { TPEAT } \\
\text { Trinsient }\end{array}$ & Iest Objective \\
\hline $1 A-1$ & $\left(l_{0 . s^{P u}} u_{0.2}\right) \mathrm{C}$ & 0 & Fast & $\begin{array}{l}\text { Na bond ejection } \\
\text { incipient fuel } \\
\text { melting }\end{array}$ \\
\hline 1A-2 & $\left(U_{0.8}{ }^{P u_{0.2}}\right) \mathrm{C}$ & o & Slow & Sapc as $1 A-1$ \\
\hline $18-1$ & $\left(U_{0.8^{P u_{0.2}}}\right) \mathrm{C}$ & 0 & Fast & $50, c$ F uel melting \\
\hline $1 \mathrm{~B}-2$ & $\left(U_{0,8} P u_{0.2}\right) N$ & 0 & Fast & Same os $2 B-1^{d}$ \\
\hline $18-3$ & $\left(\mathrm{U}_{0.8} \mathrm{Pu}_{0.2}\right) \mathrm{C}$ & 0 & STuw & Same as 1B-1 \\
\hline $1 D \rightarrow$ & $\left(\mathrm{U}_{0.8} \mathrm{P}^{\mathrm{u}_{0.2}}\right)^{\mathrm{N}}$ & o & Slow & same as $1 \mathrm{B-1}{ }^{\mathrm{d}}$ \\
\hline $1 C-1$ & $\left(U_{0.8}{ }^{P u_{0.2}}\right)^{C}$ & $8 \%$ & c & Same as 1B-1 \\
\hline $1 C-2$ & $\left(U_{0.8} P_{0.2}\right)$ & $8 \%$ & c & Same as 1B-1 \\
\hline
\end{tabular}

${ }^{3}$ The fuel will he pellets, contained in 0.310 in. 0,d, by $0.012-i n$. w.all

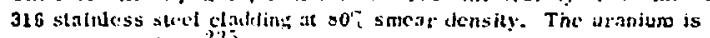
eoriched to $90 \mathrm{~s}$, in ${ }^{23 j} \mathrm{~L}$.

bast transirnts will deposit eneroy in time periods of the onder of 1 sec while s!uw transtetis will be on the orter of 10 sec.

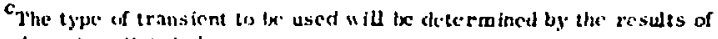
the tuiridiated clemein wists.

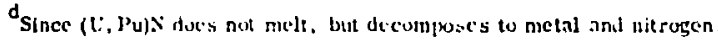
the test objectives ate deserited in terms of the ene ray rerpured to produce a given incling ill $(L, P u) C$.

\section{W. FUEL PROPEITY MEASUREMENTS}

\section{Uifferential Thermal Analysis}

(J. G. Reavis)

The program of differential thermal analysis of irradiatcd $\mathrm{UO}_{2}-\mathrm{PuO}_{2}$ fuei materials supplied by G.E.Sunnyvale is continuing. A sample of $\mathrm{UO}_{2}-25 \% \mathrm{PuO}_{2} \mathrm{ir}-$ radiated to 7.6 at. $\%$ burnup has been sealed in a $W$ capsule for observation. A Ta shim was incorporated into the weld in an attempt to improve the welding characteristics and increase the probability of achievirg a crackfree weld.

Before the capsule of irradiated fuel could be observed, however, problems appeared in the vacuum system. Portions of the system exterior to the cell have been reconditioned, but leaks apparently st ill exist inside the hot cell. 
IV. REF RF.NCES

1. R. D. Baker, "Quarterly Status Reporit on the Advaric" d Plutonium Fuels Program, April 1 to June 30, '7"' and SLxth Annual Report, FY 1972," Los Alainos Scientific Laboratory Report LA-5067-PR (1572).

2. D. L. Kell.r. "Progress on Development of Fuels and Technolugy for Advanced Reactors During July, 197. Thr urrh June, 1972," Battclle Memorial Institute Report BMI-1925 (1972).

3. I. C. Viga, "Theoretical Reactor Physics Program and First innual Report, FY 1971, "Los Alamos Scicntilic Laboratory Report LA-4738-MS (1971).

4. J. C. Vigil. "Theoretical Reactor Physics Program, October 1-December 3, 1971, "Los Alamos Scient ific Laboratory Report LA-4889 ..PR (1972).

5. J. C. Vigil, "Theoretical Reactor Physics Program, January. -March 31, 1972," Los Alamos Scientific Laboratury Report LA-4955-PR (1972).

6. R. E. Alcouffe, "A Generalized Finite Differential Diffusion Equation for Neutron Transport Computations. "Los Alamos Sclentific Laboratory Report LA-493\$-MS (1972).

\section{CORRECTION - PROJECT 463}

In LA-5067-PR, Quarterly Progress Report on the Advanced Plutonium Fuels Program, April 1 to June 30, 1972 " the figures on pages 35 and 36 are mixed up:

Fig. 463-2 -- Title is correct, but graph shown (p. 35) as Figure 463-3 should be here.

Fig, 463-3 -- Title is correct, but graph shown (p. 35) as Figure $463-4$ (on p. 36 ) should be here.

Fig. 463-4 - Title is correct, but the graph (p. 36) shown as Fig. 463-2 (p. 35) should be here. 


\title{
PROJECT 472
}

\section{ANAL YTICAL STANDARDS FOR FAST BREEDER REACTOR OXIDE FUEL}

\author{
Person in Charge: $\quad$ R. D. Baker \\ Principal Investigator: G. R. Waterbury
}

\section{INT RODUCTION}

Necessary to the development of the high quality fuels and control rods required by the LMF BR program are highly reliable analytical methods for the chemical characterization of the source waterials and the pellet products, and for the measurement of burnup and fission gases on irradiated fuels. Objectives concerned with ensuring the production of these high quality reactor materials are: (1) the continued preparation of carefully characterized calibration materials for the various analytical methods; (7) the preparation of quality control samples used for surveillance of analytical chemistry laboratory operations during periods of production; (3) continued assistance and guidance of quality assurance programs for chemical specifications sampling and analysis; (q) the development of more reliable methods of chemical analysis with emphasis on $\mathrm{O} / \mathrm{M}$ measurement, (5) the preparation of continuously updated compilations of analytical methods for these materials; (6) the analysis, as a reference laboratory, of those samples in dispute between a vendor and a purchaser. For the immediate future, these objectives are centered on the FFTF. Later, they will be extended to the LMFBR demonstration and large production phants.

Objectives concerned with irradiated LMF BR fuel examination are: (1) the development of burnup methods based on conventional mass spectrometry measurements and later by spark source mass spectrometry; (2) the development of faster burnup methods using chemical analvsis techniques; and (3) start sevelopment of analytical methods for the determination of gases in pre and post- irradiated fuels and control rod absorber materials to provide data on gas retention properties and cladding stability.

\section{ANAL YTICAL CHEMISTRY PROG "AM FOR BORON CARBIDE}

A program equivalent to that established for the production of FFTF mixed oxide fuel is being set up for the production of FFTF boron carbide pellets.

\section{A. Status of Analytical Methods and Qualification of Analytical Laboratories \\ (R. K. Zelgler, J. E. Rein, G. R. Waterbury) \\ Last year, two AEC-Internal Round Robins indicated} that analytical methods for the measurement of nine chemical properties of boron carbicle were satisfactory relative to the requirements set by HEDL for the FFTF. Copies of these methods were distributed to the three potential vendors of FFTF boron carbide pellets and a round robin with vendor participation plus two AEC laboratories (HEDL and LASL) was conducted. Only the results for total carbon and boron isotopic distribution were considered adequate for specification analyses. Either the betweenlaboratory difference or the measurement reproducibility were too large for the other seven (total boron, $\mathrm{HCl}$ soluble boron, $\mathrm{HNO}_{\mathrm{i}}$ soluble boron, soluble carbon, chlorIde, fluoride, and general metallic impurities) methods.

The three vendor laboratories were visited by HEDL, and LASL personnel to provide technical aid with emphasis on those methods where the round robin results indicated difficulties. It is believed that the discussions disclosed many likely sources of difflculty. Characterized boron carbide batches were given to the laboratories to be used for the evaluation of method modifications. 
A second vendor round robin with the same three industrial laboratories and two AEC laboratories has been started. The methods to be evaluated are the seven that llere not deemed satisfactory in the first round robin. Completion is scheduled for early November.

B. Preparation of Calibration Mate -ials and Quality Control Samples

(J. A. Pena, O. R. Simi, H. J. Kavanaugh,

J. E. Rein)

The preparation of these materials, in amounts estimated to be used by the vendor laburatories and by HEDL for the production of the FFTF boron carbide pellets, is nearing completion. Characterization of the materials, necessary for the verification of homogeneity, is under way.

\section{Status of RDT Standara's}

(J. E. Rein, R. K. Zeigler, W. H. Ashley,

O. R. Simi, G. R. Waterbury)

Jointly with HEDL, a draft of RDT standard 1 11-2 "Analytical Chemistry Methods for Control Rod Absorber Material" has been prepared and submitted to RDT for review and approval. The analytical methods included in this document are the nine presented prevlously in Section A plus gas content and water content.

A draft of RDT standard F2-8 "Qualification and Control of Analytical Chemistry Laboratories for Control Rod Atsorber Materlal Analysis, " also prepared jointly by HEDL and LASL, is essentially complete and is expected to be submitted to RDT early next quarter. This document prescribes the course of action by which analytical laboratories establish heir technicai competence to do the chemical analyses cequired for the characterization of boron carbide pellets. It also describes the quality control program that will be in effect for the continual evaluation of the analytical data that will be obtained during periods of boron carbide pellet production.

D. Studies and Improvcments of Analytical Methods (R. D. Gardner, A. L. Henicksman, W. H. Ashley)

1. Determination of Soluble B. Soluble $B$ is expected to exist in $\mathrm{B}_{4} \mathrm{C}$ as $\mathrm{B}_{2} \mathrm{O}_{3}$ and elemental $\mathrm{B}$. These minor colmponents are determined after selective dissolution of $\mathrm{B}_{2} \mathrm{O}_{3}$ in $0.1 \mathrm{M} \mathrm{HCl}$ from one sample, and tisth $\mathrm{B}_{2} \mathrm{O}_{3}$ and $\mathrm{B}$ in 1.6M $\mathrm{HNO}_{3}$ from a second sample. As the boron carbide materials cover a composition range from about $B_{12} C_{3}$ to $B_{13} C_{2}$, the possibility of dissolving $B$ from high boron content carbides (near $\mathrm{B}_{13} \mathrm{C}_{2}$ ) was inve'stigated. This was done by refluxing material described as $\mathrm{B}_{6,1} \mathrm{C}$ with $1.6 \underline{\mathrm{M}} \mathrm{HNO}_{3}$ for $4 \mathrm{~h}$ according to the method. The dissolved $B$ was $0.47 \%$ of the sample weight which was within the concentration range usually found. Then the residue from the first refluxing was separated and washed, and the relluxing with $1,6 \underline{\mathrm{MNO}} \mathrm{HNO}_{3}$ for $4 \mathrm{~h}$ was repeated. Only $0.03 \%$ of $\mathrm{B}$ was dissolved during the second refluxing, indicating that the high boron content material does not continue to dissolve signiticantly. These results indicate that the method probably is valid for materials having a wide range of boron-carbon compositions.

As we are comparing the soluble bo'on values obtained by refuxing in $\mathrm{HNO}_{3}$ with those obtained by dissolution in $\mathrm{H}_{2} \mathrm{O}_{2}$, the double leaching experiment described above was repeated using $10 \%_{0} \mathrm{H}_{2} \mathrm{O}_{2}$ as the solvent after the first leach was $0.42 \%$ as compared to $0.04 \%$ after the second leach. The small difference between $0.4 \gamma_{i}$ and $0.42 \%$ is well within the limits of variation for the $\mathrm{HNO}_{3}$ soluble $B$ in a sample. Either method secmed to be equaliy satisfactory for this measurement.

\section{Determination of Total B. Summations of to-} tal carbon, total boron, and the measured impurities have been consistently less than $100 \%$. In an attempt to determine the cause for the low resuits, we analyzed the hydrous oxides, which are discarded in the boron procedure, and found cnly negligible amounts of boron. The stability of primary standard SRM 951, following exposure to air for 1 yr, was verified by analysis. The probable cause for low results was found to be the fron contamination introduced during grinding in a diamond (steel) mortar. In the latest set of total boron analyses, the iron in the fusion solutions was found to vary from $0.18 \%$ to $0.56 \%$. This impurity interferes with the titration of the dissolved boron with $0.1 \mathrm{~N}$ NaOH. As the iron is probably int roduced in discrete particles of varying size, it may not be uniformly distributed. Although boron results could be corrected for the intereference, if each sample portion werc analyzed for $\mathrm{Fe}$, such a correction is not applicable for the carbon deternitnation. The use of a different mostar, possibly boron carbide, is recommended for grinding the samples. 
III. ANALYTICAL CHEMITSTY PROGRAM FOR FBI MLXED OXIDE FUEL

A. - Quilification of Analutical Laboratories

(R. K. Zeigler, J. E. Rein. G. R. Waterbury)

The laboratories of the two fuel vendors are in the process of becoming qualified for the analys is of the fued and sesure materials to be manufactured for the FFTF. Aid is being given to HEDL, as requested, in this project. This includes providing of calibration materials, review of the datil reported by the laboratories where discrepancies occur, and technical review of the analytical methods that are used in an attempt to trace causes of difficulty.

B. Calibration Materials and Quality Control Samples (J. A. Pena, H. J. Kavanaugh, C. J. Martel, W. M. Myers, C. B. Collier, J. E. Refm)

The quantities of these materials, estimated to be used for the qualification phase of two fuel vendors and for the first quarter of fuel protuction, were provided to HEDL in May 1972. Since that time, changes have been made in the quality assurance program that will result in an increased usage of both calibration materials and quality control samples by a factor of at least two. These changes include (1) addition of the plutonium dioxide supplier (ARHCO) to the quality assurance program, (2) increase in the production rate of fuel, (3) increased coverage from eight to nine quarters of fuel production, and (4) increases in the amount of material required for an analysis by some of the laboraturies for sume of the nalytica: methods.

The overall effect is that a very significant increase in effort will be necessary to prepare, characterize, package, and ship the materials to meet the greater needs. Materials on hand are now being packaged for shipment to HEDL and the preparation of new material batches has been started.

C. Status of RDT Standards

(J. E. Rein, R. K. Zeigler, G. R. Waterbury)

RDT approved the draft of RDT standard F11-1

"Analytical Chemistry Methods for Mixed Oxide Fuel" preaared by HEDL and LASL. A draft of RDT standard F:-6 $\because$,ual ification and Control of Analytical Chemistry Laborat: ties for Mixed Oxide Fuel Analysis" should be conphes-t in the near future and submitted to RDT for review and approval.

\section{Development of Analytical Methods}

\section{Determination of Burnup}

$$
\text { (S. F. Marsh, J. E. Rein }
$$

The most reliable technique for the determination of nuclear fuel burnup is based on isotope dilution mass spectrometry of fission product neodymium, uranium, and plutonium using the triple spike technique. For laboratories without a mass spectrometer or those having a large rout ine sample load, a burnup method which requires less and lower-cost equipment is needed. Such a method would relate the number of fission events (using a selected fission product element or group of elements as the fission monitor) to the total heavy element content (based on postirradiation uranium and plutonium). The proposed scheme is a chemieal separation of the selected fission monitor, uranium, and plutonium from a dissolved fuel sample fol lowed by chemical measure nents of each of the three components by a technique such as spectrophotometry.

The fission procucts most useful as fission monitors for $F B R$ fuels arc rare earths and elemental zirconium. Of these two, tutal of the rare carths is preferable because the fission yield is higher and more constant for different fissile nuclides.

A promising separation scheme being investigated is retention of the rare earth group on a cation-exchange column from ethanol-hydrochloric acid medium while $U, P u$, $A m-C_{1}$, and mar: fission f'oducts pr. s through :o an anion-exchange column which retains $U$ and $P u$. The rare earths would be eluted from the first column with aqueous hydrochloric acid and purified further, if necessary, prior to their chemical determination as a group. Plutonium and uranium would be sequentially eluted from the second column with $12 \underline{\mathrm{M}} \mathrm{HCl}-0.1 \underline{\mathrm{M}} \mathrm{HI}$ and $0.1 \underline{\mathrm{MCl}}$, respectively, prior to their chemical determination.

The most difficult separation to achieve in the proposed scheme is that of the rare earths from the trivalent actinides Am and $\mathrm{Cm}$. This separation it; desirable for two reasons: to minimize the radiological hazard to personnel and to avoid the error in the rare (arth determination duc to trivalent actinide cratributions. An investigation oi the cation-exchange beliavior of Eu and Am bared on batch-contact experiments covering a 1 ide range of 
ethanol-hydrochloric acid mexthres has indicated that nearly complete sept ration $: i$ the two elements can be achieved. As the equilibrium rates in ethanol-hydrochloric acid media a much slower than for aqueous media, additional stud:rs to est ihlish the conditions for successful column operation are needed.

2. Investigation of toe Determination of $O / M$ (G. C. Swanson)

The oxygen to heavy-metal-atom ratio $(O / M)$ for mixed $(\mathrm{C}, \mathrm{Pu}) \mathrm{O}_{2}$ fuels is an i:oportant parameter affecting sưel ōperating charactéristics. The most widely used measurements of $\mathrm{O} / \mathrm{M}$ are thermogravimetric in which the weight change of the sample is measured when the sample is subjectej to conditions of temperature and gas composition which will produce stoichiometric $(\mathrm{O} / \mathrm{M}=$ 2. 000) oxide.

These conditions have been subject to much controversy: tempers iures from $750^{\circ} \mathrm{C}$ to $1000^{\circ} \mathrm{C}$ and several gas mixtures are used. Standard reference materials having certificd $O / M$ ratios do not exist, and the best reference materials now available are $\mathrm{UO}_{2}$ and $\mathrm{PuO}_{2}$ carefully prepared by burning the highly pure metals. Changes in stoichiometries of these two oxides and their mixtures can be calculated readily from initial metal weights, but these prepared axides differ from the solid solution mixed (U, Pu) axides because of the expected differences in chemical potentials of mechanical mixtures and true solid solutions.

A study of thermogravimetric measurements of $O / M$ has been started. A Mettler recording vacuum thermoanalyzer has been obtained and modified for use in a glovebox. Installation of the thermobalance is essen.ialiy complete. Several accessories for the balanre, including a high vacuum system, a DTA amplifier, and an automated digital data logging system, are expected to be installed next quarter. As installation of the high vacuum system will require access to the balance interior, $\alpha$-active material will not be handled in the apparatus prior to this installation. 